\title{
OTICIAS DE PLATERÍA Y PLATEROS EN LA
CATEDRAL DE VALENCIA (1775-1931)
}

FRANCISCO DE PAULA COTS MORATÓ

Universitat de València

Francisco.Cots@uv.es

Resumen: Los acuerdos del cabildo de la catedral de Valencia quedan recogidos principalmente en los protocolos notariales de la Seo hasta 1774. A partir de 1775, es el secretario de la corporación el que recoge en libros sus deliberaciones. Tomando como partida esta última fuente, recogemos cuantas noticias sobre platería y plateros quedan anotadas en ella hasta 1931, pues los años siguientes no se conservan. Desde 1939 hay de nuevo Actas Capitulares, pero no están todavía a disposición del investigador. En las Deliberaciones Capitulares se recogen el nombramiento del platero de la catedral, las donaciones, los encargos del cabildo así como las fundiciones de plata de 1812 y 1823.

Palabras clave: Platería / plateros / catedral de Valencia / noticias de archivo / Arte Valenciano.

Abstract: The agreements of the Valencia chapter were compiled in the notarial protocols of the Cathedral until 1774. From 1775 the secretary of the corporation gathers its deliberations in books. Taking this latter source as starting point, we gather all the news of silverware and goldsmiths that were compiled in those books until 1931, since the ones from the following years did not survive. From 1939 there were chapter acts again, but they are not yet available for researchers. In the chapter deliberations were gathered the appointment of the Cathedral's goldsmiths, donations, commissions of chapters as well the silver foundries of 1812 and 1823.

Key words: Silverware / goldsmiths / Cathedral of Valencia / notes from archive / Valencian Art.

Desde hace mucho tiempo trabajamos sobre platería y plateros en Valencia. ${ }^{2}$ Hemos puesto de relieve la complejidad de su examen corporativo, obradores y personalidades artísticas en la Edad Moderna. La labor de recuperación de noticias referidas a estos temas continúa para nosotros en la actualidad, centrada desde hace unos años en la catedral de Valencia. Cabe decir que el siglo XV es una época de gran esplendor y la centuria de la formación del Tesoro. Esta palabra, a diferencia de lo que significa hoy en día, se refería en la Edad Media al conjunto de las reliquias de un templo. Con los años, indicó las piezas de oro, plata y piedras preciosas que poseían las iglesias y monasterios, porque de estos materiales estaban labrados los relicarios que las contenían. Para su mantenimiento y la factura de otras nuevas, fue necesaria la presencia de un platero contratado por el cabildo permanentemente. La secuencia de todos ellos, desde 1500, es conocida en Valencia aunque hay algunos vacíos documentales. El cargo debió de existir desde el siglo XV. También ha quedado registrada la calidad y cantidad de las obras que allí había, con sus expolios a causa de guerras, modas o periodos anticlericales y revolucionarios.

Las líneas que siguen informan de las noticias sobre platería y plateros obtenidas de la consulta de

\footnotetext{
* Fecha de recepción: 15 de abril de 2017 / Fecha de aceptación: 9 de julio de 2017.

1 Este trabajo se integra en el proyecto de investigación "La catedral barroca. Iglesia, sociedad y cultura en la Valencia del siglo XVII", del Ministerio de Economía y Competitividad. HAR-2016-74907-R.

2 El autor agradece la ayuda de Fernando Castelló Doménech, Amelia Codina Juan, Andrés de Sales Ferri Chulio, Dra. Amelia López-Yarto Elizalde, Dr. Pablo Márquez Caraballo, Juan Ignacio Pérez Martínez, Dr. Vicent Pons Alós, Javier Sánchez Portas, Dr. Jaime Sancho Andreu, Dr. Mateu Rodrigo i Lizondo, Inmaculada Traver Badenes y José Vives Carrió.
} 
los Libros de Deliberaciones del Cabildo entre 1775 y $1931 .{ }^{3}$ La razón de escoger esta cronología se debe a que las Actas Capitulares quedan referidas, junto con otra serie de informaciones, en los protocolos notariales de la metropolitana hasta 1774. A partir de 1775, y hasta la actualidad, salvo algún vacío, son libros independientes los que recogen los acuerdos del cabildo por su secretario. La Guerra Civil (1936-1939) marca un hito importante en la Seo y también justifica las fechas elegidas. Algunas de estas noticias, especialmente las referidas a relicarios, son conocidas desde 1909, cuando Sanchis Sivera, el historiador de la catedral, publicó su Guía. ${ }^{4}$ Sin embargo, el canónigo no indica muchas veces la fuente, punto que aquí se subsana. También otro investigador ofreció algunos datos en fechas recientes. ${ }^{5}$ En la búsqueda por documentar a los plateros catedralicios y sus obras, revisamos hace un tiempo la Fábrica desde 1500 y la Tesorería desde 1600, labor que sigue a día de hoy. De ello dimos cuenta en varias publicaciones anteriores a esta. Corresponde en esta ocasión poner de relieve quiénes estaban al frente de la plata así como las obras que se encargan o donan al Tesoro durante los siglos XIX y parte del $X X$, especialmente después de las fundiciones de 1812 y 1823 . Es en el primero de estos años cuando son fundidas las piezas principales en Palma de Mallorca por la Regencia de España. Sabemos que no fue este el único ejercicio del que hay que lamentar pérdidas así como también que son muchas las piezas de plata conservadas correspondientes a esas dos centurias antes referidas.

La serie documental que nos ocupa relata las vicisitudes por las que pasa el clero de la Metropolitana así como todo aquello que repercute en el devenir diario de la corporación. Sus relaciones con el prelado, con el Gobierno de España, encargos de obras, donaciones y muchos asuntos más. El tratamiento que tiene el cabildo como corporación desde tiempo ha es el de ilustrísimo, pero, en 1879, el rey Alfonso XII, a petición del arzobispo -entonces don Antolín Monescillo y Viso (18111892) - les concede el de excelentísimo. Así, en la memoria de la Palabreta del 24 de mayo de 1879, leen una carta del prelado donde se lo hace saber. Los capitulares lo oyen "con la más viva satisfacción" y acuerdan felicitar al prelado y darle las gracias. $^{6}$

\section{Noticias de plateros}

Las referencias a orfebres no son numerosas en esta serie documental. Una de las primeras es el nombramiento del nuevo titular de la Seo en el ochocientos. En la sesión del 15 de marzo de 1803, el cabildo "eligió y nombró en platero de esta santa yglesia a Josef Carlos Quinzà" en los mismos términos y circunstancias que había servido su padre. ${ }^{7}$ Ya advertíamos que José Carlos (1802-1847) podía ser hijo de Bernat Quinzà (1752-1803) ${ }^{8}$ como aquí se confirma. Antes de este último, según sabemos por otras fuentes, había desempeñado el cargo su padre Gaspar (17001783). Este fue designado el 1 de julio de 1767, ${ }^{9}$ cuando nos dicen que "Vicente Entreaygues no puede continuar en el encargo de platero de esta santa iglesia", ${ }^{10}$ y allí seguirá hasta su muerte. Tras el fallecimiento de otro artista como es Gaspar Lleó (1701-1742), Lluís Vicente, mayor (1676-1757) es nombrado orfebre de la Seo el 22 de agosto de 1742. ${ }^{11}$ Su hijo, Lluís Vicente, menor (1702-1761) lo es el 22 de abril de 1758, cuando ya había

\footnotetext{
3 Desde 1932 y hasta 1939 no hay Libros de Deliberaciones. Cfr. R. Chabás Llorens, Índice del Archivo de la Catedral de Valencia. Valencia: Generalitat Valenciana, 1997, p. 170. Debieron de ser unos años muy convulsos y lo que menos necesitaban era que se conociera quiénes formaban parte del cabildo y los acuerdos, si los hubo, serían lo más secretos posible. Las Deliberaciones Capitulares posteriores a 1939 no están aún a disposición de los investigadores.

${ }^{4}$ SANCHIS SIVERA, José, La catedral de Valencia. Guía histórica y artística. Valencia: Imprenta de Francisco Vives Mora, 1909 (Ed. facsímil Valencia, 1990).

5 PINGARRÓN-ESAÍN, Fernando. "La reposición tardía del retablo mayor de la catedral de Valencia, elogiado en el siglo XVIII". En: CALLADO ESTELA, Emilio (Ed). La catedral ilustrada. Iglesia, sociedad y cultura en la Valencia del siglo XVIII. Vol. 2. Valencia: Institució Alfons el Magnànim-Diputació de Valencia, 2014, pp. 373-415. Este autor acostumbra a no referir las publicaciones anteriores a sus "estudios".

${ }^{6}$ Archivo de la Catedral de Valencia = ACV. Leg. 402. Libro de Deliberaciones. 1878-1879, ff. 141v-142. OLMOS Y CANALDA, Elías. Los prelados valentinos. Valencia: Semana Gráfica, S. A, 1949, p. 321.

7 ACV. Leg. 330. Libro de Deliberaciones. 1803, f. 14v.

${ }^{8}$ COTS MORATÓ, Francisco de Paula. "Plateros en la catedral de Valencia durante el siglo XVIII". En: RIVAS CARMONA, J. (coor.). Estudios de Platería. Murcia: Publicaciones de la Universidad de Murcia, 2007, p. 87.

${ }^{9}$ ACV. Leg. 1631. Llibre de posessions i salaris, f. 200.

10 ACV. Leg. 3333. Protocolos. Notario Pedro Rodrigo, f. 97.

11 ACV. Leg. 1631. Llibre de posessions i salaris, f. 171v.
} 
muerto el mayor. ${ }^{12}$ El protocolo notarial indica que "ha servido dicho empleo en las ausencias y enfermedades de su padre"..$^{13}$ Tiempo más tarde, Vicent Entreaïgues (1736-1767), antes referido, es maestro catedralicio desde el 24 de noviembre de 1761. ${ }^{14}$ El protocolo notarial hace saber que los canónigos, "de su grado y cierta ciencia, en virtud de la presente escritura, nombran para dicho empleo a Vicente Entreaguas, maestro platero, vecino de esta ciudad, con todas las utilidades correspondientes a dicho empleo, según y en la misma forma que le han tenido los antecesores en el mismo". ${ }^{15}$ Advertimos que el cabildo informa que lo nombra "de su grado y cierta ciencia", indicando que es soberano en esta decisión y lo designa por su propia voluntad, no por los méritos del beneficiado ni porque este haya ganado un concurso.

Pocas noticias más como la primera que se ha dado nos deparan los Acuerdos Capitulares. Así, en el Cabildo del 16 de diciembre de 1895, el platero José Navarro, de quien conocemos pocas referencias, $^{16}$ presenta una cuenta de los trabajos hechos para la catedral desde 1889 hasta esa fecha ${ }^{17}$ y los capitulares acuerdan que la Comisión de Hacienda provea lo que hay que hacer. ${ }^{18}$ El 2 de enero de 1896 el presidente del cabildo indica que Navarro le ha manifestado su deseo de trabajar gratuitamente para la Seo, lo que induce las sentidas gracias de la corporación. ${ }^{19}$

Como se verá muchas obras del siglo XIX y XX son donaciones para la catedral. Precisamente por es- to no figuran en esta serie los artistas que las labraron y muchas veces tampoco su coste.

\section{Obras que costea la catedral}

La primera mención referente a la hechura de nuevas obras de plata pagadas por la catedral la tenemos el 10 de abril de 1776. Ese día, el cabildo comisiona a los canónigos Josep Blanch (1762$1783)^{20}$ y Joaquín Segarra (1767-1790) para que manden labrar los candeleros de plata que juzguen necesarios para el servicio de la Seo, así como componer la Urna del Monumento. ${ }^{21}$ El 15 de abril de 1777 dichos canónigos presentan a sus compañeros el modelo de los candeleros. Estos mandan se hagan los que puedan de la plata del cuarto del Depósito

procurando la mayor conveniencia en las hechuras, igualdad en su peso y evitando molduras para que / se conserven con limpieza y hermosura y, sucesivamente, se renueven, de poco en poco, los antiguos a fin de que sean todos uniformes. ${ }^{22}$

El 2 de junio de ese mismo año Josep Blanch lleva al cabildo dos candeleros nuevos de plata labrados según las directrices dadas, que "parecieron bien al ilustrísimo cabildo y acordó continuassen su comissión y que se hiziessen los restantes como aquellos dos de la muestra". ${ }^{23}$ Mucho tiempo después, el 8 de agosto de 1791, los canónigos, a petición de Bernat Quinzà, acordaron abonarle quinientas cuarenta libras, cinco sueldos y seis dineros, a razón de siete libras de hechuras por onza

12 ACV. Leg. 1631. Llibre de posessions i salaris, f. 193. Véase COTS MORATÓ, Francisco de Paula. "Platería y plateros de la catedral de Valencia, según los libros de tesorería (1700-1772)". En: CALLADO ESTELA, E. (ed.). La catedral ilustrada. Iglesia, sociedad y cultura en la Valencia del siglo XVIII. Valencia: Alfons el Magnànim-Diputació de Valencia, 2015, Vol 3, p. 363, donde se deshace el error entre Lluís Vicente, mayor, y Lluís Vicente, menor.

${ }^{13}$ ACV. Leg. 3307. Protocolos. Notario José Gargallo, f. 627v.

${ }^{14}$ ACV. Leg. 1631. Llibre de posessions i salaris, f. 195v.

${ }^{15}$ ACV. Leg. 3313. Protocolos. Notario José Gargallo, f. 308v.

16 Sabemos que un José Navarro Oliver es examinado, en clase de matriculado, de maestro el 12 de julio de 1882, pero desconocemos si es la misma persona. Cfr. COTS MORATÓ, Francisco de Paula. El examen de maestría en el Arte de Plateros de Valencia. Los Libros de Dibujos y sus artífices (1505-1882). CD. Ap. Doc. 2.4. Listas de maestros aprobados sin realizar examen. Doc. $n^{\circ} 101$.

17 ACV. Leg. 520. Doc. 126. La cuenta asciende a 3.710 reales. Son reparaciones ordinarias de la plata como blanquear, bruñir soldar incensarios, bandejas, sacras, colocar clavos en la plata de misales, etc.

18 ACV. Leg. 408. Libro de Deliberaciones. 1895-1897, f. 45v.

19 ACV. Leg. 408. Libro de Deliberaciones. 1895-1897, f. 48.

20 Para las cronologías de los canónigos del siglo XVIII véase PONS ALÓS, Vicente y CÁRCEL ORTí, Ma Milagros. "Dignidades y canónigos de la catedral de Valencia en el siglo XVIII". En: CALLADO ESTELA, E. (Ed.). La catedral ilustrada. Iglesia, sociedad y cultura en la Valencia del siglo XVIII. Valencia: Alfons el Magnànim-Diputació de València, 2013. Vol. 1, pp. 103-125. Las del XIX proceden de ACV. Leg. 689. Libro de Canónigos y Leg. 690. Libro donde consta el día, mes y año en que murieron arzobispos... Estas últimas cronologías, por el momento, son más imprecisas. Seguramente cambiarán en estudios posteriores.

21 ACV. Leg. 303. Libro de Deliberaciones. 1775-1776, f. 89v.

22 ACV. Leg. 304. Libro de Deliberaciones. 1777, ff. 83-83v.

${ }^{23}$ ACV. Leg. 304. Libro de Deliberaciones. 1777, ff, 102v.-103. 


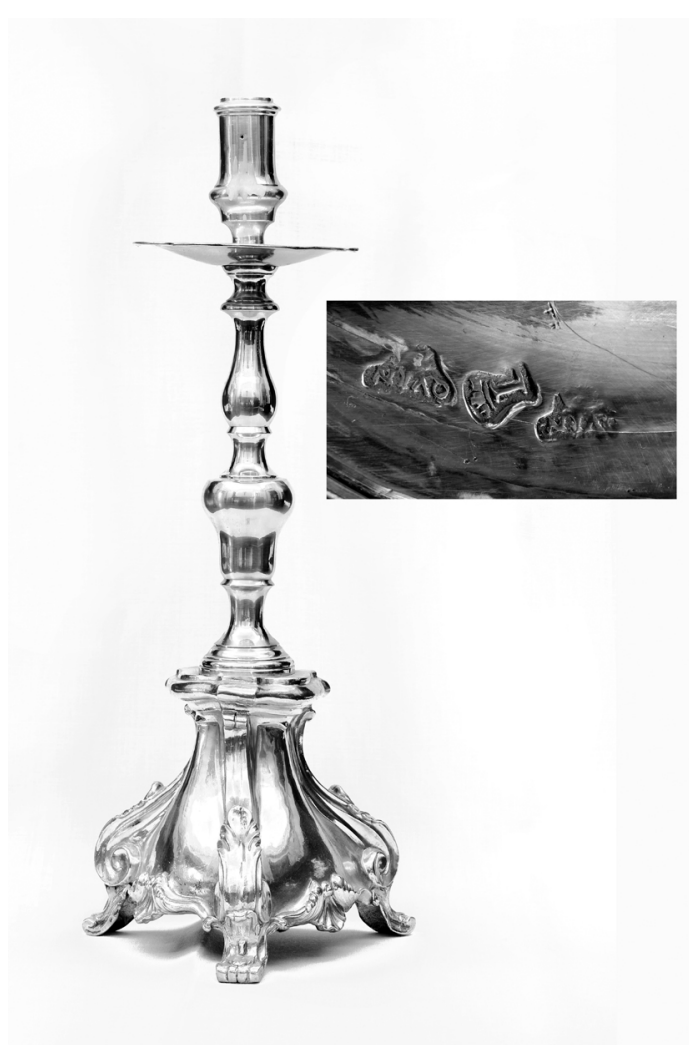

Fig. 1. Gaspar Quinzà. Candelero. 1777. Foto A. Sáiz. (c) Archivo de la Catedral de Valencia.

de los candeleros. Bernat acudió a los capitulares exponiéndoles que su padre había labrado ciento cuarenta y cinco de estos y no había cobrado entonces lo debido. ${ }^{24}$

La catedral conserva seis de estos ciento cuarenta y cinco candeleros que hubo para las gradas del Monumento. Solo dos están marcados con el sello del obrador de los Quinzà, que en este momento encabeza Gaspar. Son de plata blanca y con pie triangular (fig. 1). Los adornan algunas rocallas y pequeñas hojas de acanto. Son casi lisos, sin lenguaje icónico. Hace un tiempo indicábamos que habían adoptado el clasicismo en detrimento de la rocalla, lo que parecía razonable. ${ }^{25}$ Ello es cierto, pero tengamos presente que el cabildo los quería sin molduras para que se conservasen limpios y hermosos el mayor tiempo posible. En estas piezas observamos cómo hay un intento práctico de conservación que coincide con el cambio del lenguaje ornamental que se da en toda España.

Las custodias fueron un vaso litúrgico que entró en el Tesoro entre 1775 y 1931 con relativa frecuencia. El 1 de agosto de 1797 el canónigo-magister, Antonio Valentín Criado (1776-1811), propone hacer un viril nuevo, pues había en la catedral joyas con gemas y muchas piedras preciosas de los espolios de los arzobispos difuntos. El cabildo le encarga "para que mande formar los dibuxos y se los reporte antes de ponerse en egecución". ${ }^{26}$ Desconocemos si el trabajo se llevó a cabo. Sin embargo, y a pesar de las donaciones, una de las empresas que más preocupó a los canónigos después de 1812 fue la hechura de una nueva custodia procesional, porque la antigua -la de Castellnou, de mediados del siglo XV- había desaparecido en la fundición de Palma de Mallorca. El cabildo, ante la escasez de medios, se las vio y deseó para la fábrica del nuevo viril, muy necesario para la procesión anual del Corpus Christi, así como para expresar la dignidad y magnificencia de la metropolitana. El resultado final no puede ser más decepcionante, pues labraron una custodia muy sencilla que, junto con sus andas de madera, desapareció el 21 de julio de 1936.

Parece que las gestiones tomaron consistencia el 23 de enero de 1818, cuando el canónigo Antonio Roca (1784-1823) expone a los capitulares que ha "procurado un diseño muy bueno para la custodia nueva del Santísimo Sacramento. Y su ylustrísima acordó se uniese a los otros dibujos y que continuase en tomar conocimientos sobre la materia para que con presencia de todo pueda salir una obra buena y acertada". ${ }^{27}$ Unas semanas más tarde, el 3 de febrero, el mismo Roca pide nombren una comisión para la ejecución de la nueva custodia, muestre los diseños que se puedan hacer y vea las existencias. El cabildo lo acepta y designa la comisión solicitada. ${ }^{28}$ Ese mismo año, el 2 de mayo, Roca acredita la urgencia de componer la custodia del Santísimo Sacramento porque está

\footnotetext{
24 ACV. Leg. 318. Libro de Deliberaciones. 1791, ff. 115v.-116v. Véase también COTS MORATÓ, Francisco de Paula. "El final de un tesoro: la plata superviviente de la seo (1700-1825)". En: CALLADO ESTELA, E. (ed.). La catedral ilustrada. Iglesia, sociedad y cultura en la Valencia del siglo XVIII. Valencia: Alfons el Magnànim-Diputació de València, 2014, vol. 2, f. 425.

25 COTS MORATO, Francisco de Paula, 2014 (nota 24), pp. 435-436.

${ }^{26}$ ACV. Leg. 324. Libro de Deliberaciones. 1797, f. 78v.

27 ACV. Leg. 345. Libro de Deliberaciones. 1818, f. 34.

28 ACV. Leg. 345. Libro de Deliberaciones. 1818, f. 38v. La comisión estaba formada por Antonio Roca, Josep Rivero, Onofre Soler y Juan Bautista Pérez Caballero.
} 
cercana la fiesta del Corpus Christi. El cabildo comisiona a Antonio Roca y a Naudín "para que lleven a efecto la composición de dicha custodia, como en el año anterior". ${ }^{29}$ Como vemos, se están refiriendo a una pieza de carácter provisional. Las cosas no parecen solucionarse, pues el 16 de mayo, Antonio Roca expone que, pese a la comisión, si no hay medios no pueden hacer nada. El cabildo, entonces, se compromete a pagar dos mil libras cada año y pide que el diseño debe serle presentado así como también ser "aprobado por la Academia de San Fernando de la corte". ${ }^{30}$

La custodia fue trabajada por el platero de la catedral José Carlos Quinzà y debió de estrenarse en la fiesta del Corpus Christi de 1819, aunque quizá tuvo mejoras y arreglos durante todo el ochocientos. Sabemos que el 8 de julio, oído el informe de la Junta de Hacienda sobre el memorial de Quinzà, el cabildo acordó "se le pague la mitad del importe de la obra que ha hecho para la custodia en este año, reteniéndose el fabriquero la otra mitad". ${ }^{31}$ Un par de años más tarde, el 25 de abril de 1821, el cabildo comisiona al Sr. Rivero (1785-1838) "para que tratase con los artífices sobre habilitar la custodia en que deve llevarse al Señor en la procesión del Corpus y se reportare al cabildo el costo". ${ }^{32}$ Desconocemos si las andas de entonces fueron las mismas que conocemos por una fotografía de ca. 1930. Sí queda claro que, el 2 de junio de 1824, el cabildo acuerda que se coloquen en la custodia "los quatro faroles que antes se llevaban". ${ }^{33}$ Estos fueron encargados en 1808. El 8 de febrero de ese último año, el canónigo Antonio Roca expone a sus compañeros la conveniencia de labrar unos faroles para la custodia del Corpus. La razón era que los candeleros que lleva se apagan muchas veces por el aire y el movimiento. El cabildo convino que los canónigos Roca y Rivero se en- cargasen, pero que, antes de mandarlos hacer, les mostrasen el modelo o el diseño. Los faroles, insistía el cabildo, han de guardar "el mismo orden gótico que lleva la misma custodia". ${ }^{34}$ Fueron realizados por el platero de la catedral José Carlos Quinzà. Eran dorados e incorporaban cristales. ${ }^{35}$ Estos se conservaban en 1907, aunque ya no eran usados para el cometido que fueron concebidos. ${ }^{36}$ Desconocemos si el conjunto -Custodia y andasera monumental, pero nos atreveríamos a decir que no. Sin embargo, el cabildo preveía cierto empaque, ya que, el 8 de junio de 1826, deciden que, en lo sucesivo, sean dieciséis portadores los que lleven la custodia en el día del Corpus Christi y se pongan los faroles para que no falte la luz. ${ }^{37}$ Los dieciséis portadores, junto con el palio, seguramente aumentarían la grandiosidad de una obra que no la poseía en absoluto.

Por fotografía vemos que la Custodia está en el alto de unas andas de madera -peana procesional-, seguramente doradas y plateadas, con el Ave Fénix, símbolo de la resurrección tallada en la parte frontal de la peana (fig. 2). El viril es una pieza de astil simple, con molduras y nudo de jarrón. Es de tipo sol, con pocos rayos, círculo de nubes, espigas y racimos. Estaba rematado por una cruz. Advertimos poco lenguaje icónico. ${ }^{38} \mathrm{El}$ Inventario de 1907 la refiere de este modo: "Custodia del Santísimo Sacramento de plata / y madera. Una mesa carro para sostenerla y transportarla". ${ }^{39}$ Sanchis Sivera no la nombra entre las seis andas de plata de la Seo, ${ }^{40}$ lo que prueba que no formaba parte de ellas y que solo era de plata el viril, pero no la peana ni los faroles. Estos últimos debieron de colocarse a fines del siglo XIX o principios de la centuria siguiente en sustitución de aquellos "góticos" labrados en 1808 para la gran torre medieval de más de tres metros de altura.

\footnotetext{
${ }^{29}$ ACV. Leg. 345. Libro de Deliberaciones. 1818, ff. 134v.-135.

30 ACV. Leg. 345. Libro de Deliberaciones. 1818, ff. 141v.-142.

31 ACV. Leg. 346. Libro de Deliberaciones. 1819, f. 118v.

32 ACV. Leg. 348. Libro de Deliberaciones. 1821, f. 66v.

33 ACV. Leg. 351. Libro de Deliberaciones. 1824, f. $83 \mathrm{v}$.

${ }^{34}$ ACV. Leg. 335. Libro de Deliberaciones. 1808, f. 26.

${ }_{35}$ COTS MORATÓ, Francisco de Paula. "Plateros en la catedral de Valencia durante el siglo XIX". En: RIVAS CARMONA, J. (coor.). Estudios de Platería. Murcia: Publicaciones de la Universidad de Murcia, 2008, pp. 166-167.

36 "Cuatro faroles de metal góticos de la antigua custodia, con fundas de vaqueta, que sirven hoy para el altar que se levanta en la plaza de Santo Domingo, en la entrada solemne de los prelados". Cfr. ACV. Leg. 6065. Inventario de 1907, f. 13.

37 ACV. Leg. 353. Libro de Deliberaciones. 1826, f. 47v.

38 COTS MORATÓ, Francisco de Paula, 2008 (nota 35), pp. 168-170.

39 ACV. Leg. 6065. Inventario de 1907, ff. 16-17.

40 SANCHIS SIVERA, José, 1909 (nota 4), p. 433. Estas eran las de San Vicente Ferrer, San Luis Bertrán, la del Santo Cáliz, San Luis Obispo, San Vicente Mártir y Santo Tomás de Villanueva.
} 


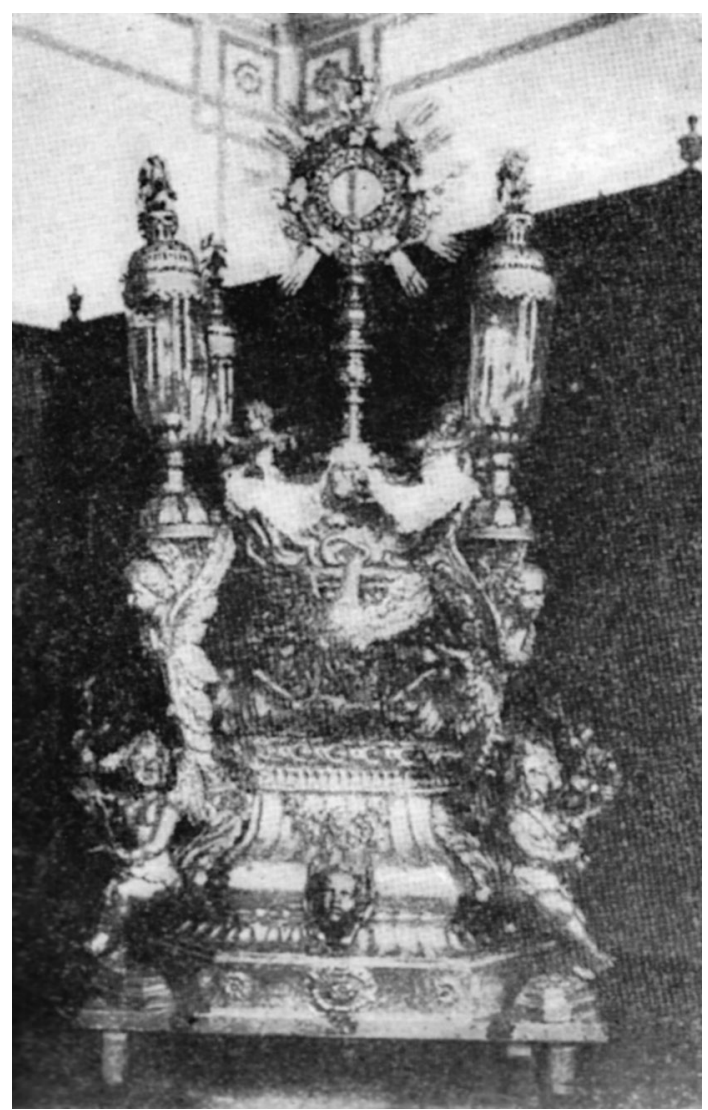

Fig. 2. José Carlos Quinzà. Custodia procesional. 1819. (c) Foto Archivo de la Catedral de Valencia.

Muchos años después de costear esta, el cabildo contribuyó a otra custodia esta vez para la capilla de Nuestra Señora del Milagro, titular de la catedral. El 9 de enero de 1879 el deán invitó al cabildo a suscribirse con alguna cantidad para pagar el nuevo viril de la iglesia del Milagro. El cabildo da dos mil reales que se repartirán entre todos los capitulares. ${ }^{41}$ La custodia estaba terminada en 1886 y la realizó el platero Timoteo Xerri (1838-1886). Era una obra riquísima y estaba adornada con muchas piedras preciosas. Sustituía a otro viril robado. ${ }^{42}$

Si las andas sobre las que iba la Custodia del Corpus Christi no eran de plata, el cabildo costeó otras dos de este metal para las imágenes de San
Luis Obispo y de San Vicente Mártir. El 15 de septiembre de 1789, el canónigo Antonio Valentín Criado, administrador de la Fábrica, expone a los capitulares que sería conveniente hacer unas andas para llevar el cuerpo de san Luis Obispo y la imagen de Santiago apóstol, pues las que utilizan en las procesiones claustrales eran de madera "y estavan ya indecentes". Criado propone se fabriquen unas nuevas "con planchas de plata en lo exterior y demás extremos que convenga y tengan uniformidad con los demás santos que se llevan en las procesiones generales, a fin de que pueda acompañarles san Luis Obispo". Hace saber, además, que su coste será de más de dos mil quinientas libras. El cabildo acuerda que se labren bajo la dirección del canónigo-fabriquero. ${ }^{43}$ Las realizó el platero de catedral Bernat Quinzà y en ellas intervino el escultor valenciano José Cotanda (1752-1802). Las andas fueron terminadas en 1790 y costaron nueve mil trescientas libras, diez sueldos y trece dineros. ${ }^{44}$ Desaparecieron el 21 de julio de 1936.

Las de san Vicente Mártir son un poco más tardías. El 15 de abril de 1806 el canónigo-magister Josep Rivero comunica que ha mandado quemar ornamentos viejos e inservibles y que, junto con otra plata deteriorada, ha recogido trescientas onzas de este material. Piensa que podrían hacerse unas andas para la imagen de San Vicente Mártir, pues todos los años hay que pedirlas prestadas al convento de Santo Domingo para llevarla en la procesión del Corpus Christi, lo que es indecoroso. El cabildo está de acuerdo y encarga del asunto al citado canónigo ${ }^{45}$ Las andas las trabajó el platero de la Seo José Carlos Quinzà ese mismo año y formaban cuatro anchas caídas de plata blanca con roleos, medallones y guirnaldas repujados en el frente de cada una de ellas. Muchos años después, en el Cabildo del 25 de enero de 1862, el canónigo-fabriquero informa de un percance acaecido a este conjunto. Al trasladarlo desde la sacristía al Aula Capitular antigua "donde por costumbre lo depositaba para su custodia", se rompieron las barras de las andas, cayendo la imagen al suelo y estropeándose el brazo derecho. El cabildo manda lo reparen. ${ }^{46}$ Desaparecieron el 21 de julio de 1936.

\footnotetext{
${ }^{41}$ ACV. Leg. 402. Libro de Deliberaciones. 1878-1879, f. 100v.

42 COTS MORATÓ, Francisco de Paula, 2008 (nota 35), pp. 185-186.

${ }^{43}$ ACV. Leg. 316. Libro de Deliberaciones. 1789, ff. 140v.-141v.

${ }^{44}$ COTS MORATÓ, Francisco de Paula, 2007 (nota 8), p. 82.

${ }^{45}$ ACV. Leg. 333. Libro de Deliberaciones. 1806, ff. 109-109v.

${ }^{46}$ ACV. Leg. 389. Libro de Deliberaciones. 1862, f. 8.
} 
Las seis andas de plata eran el orgullo de la catedral después de la fundición de 1812. Salían en la procesión anual del Corpus Christi y en las festividades de cada titular. Ello quedaba recogido en el habla popular de la ciudad, pues cuando sus pobladores querían indicar que venía alguna cosa excelente decían "Ahora, las andas de plata". De la misma manera, cuando los valencianos presumían de la Seo y sus tesoros, uno de los modos de hacerlo era el siguiente: "Tenim mosatros unes andes de plata que valen més que tota la Catedral de Toledo" ${ }^{47}$

Una de las tipologías que más frecuentemente figura en esta serie documental son los relicarios. Se labran tanto costeados por la Fábrica como regalados por algunos canónigos que quieren, seguramente por devoción, reponer y aumentar el Tesoro. El 1 de diciembre de 1787, el cabildo acuerda encargar un relicario de plata para un hueso del beato Gaspar Bono donado a la catedral por los Padres Mínimos del convento de Valencia. ${ }^{48}$ Bernat Quinzà lo labró. ${ }^{49}$ Unos años más tarde, el 2 de enero de 1792, ordenan hacer otro del mismo metal para una reliquia del Beato Andrés Hibernón. ${ }^{50}$ Ya en el siglo XIX, el 14 de abril de 1812, el capitular Josep Rivero presenta un dibujo para un Lignum Crucis. Este leño había pertenecido al monasterio jerónimo de San Miguel de los Reyes con anterioridad. El cabildo conviene "se cierre dicha santa reliquia en un relicario o guarnición por ahora de plata, con la decencia que permite el estado de la Fábrica". ${ }^{51}$ No parece que se hiciera, pues el relicario es de madera. Eran años difíciles por la gran necesidad económica, pero aun así, no cesa el flujo de encargos. El 1 de enero de 1816, el canónigo Roca expone que la Camisita del Niño Jesús era venerada primitiva- mente en una urnita y, en la actualidad, se manifestaba en un cubito de cristal. Como estaba enrollada se privaba al pueblo de verla. Por ello pide hacer una urna semejante a la antigua. El cabildo acepta la proposición, ${ }^{52}$ pero la verdad es que el Relicario de la Camisita hoy es un cilindro como lo era en 1816 y no se ha innovado nada en él. ${ }^{53}$

La dificultad monetaria del cabildo y de la catedral la advertimos en el cambio de material en el que se fabrican gran número de objetos. Si antes las lámparas eran de plata, después de 1812 serán de bronce, el metal más común de la Seo. El 1 de agosto de 1826 convienen se construya una lámpara para la capilla de la Virgen del Rosario de la administración del canónigo Vicente María Carrillo y Mayoral (1769-1813), donde hay bastante fondo. ${ }^{54}$ Tiempo después, el 8 de abril de 1829, deciden reponer todas las de los altares y las de las capillas..$^{55}$ El 15 de junio de ese mismo año mandan colocar una lámpara en la capilla de San Miguel. La pagan de los atrasos de la mensa canonical. ${ }^{56}$ El proceso termina el 1 de marzo de 1832 cuando las han repuesto todas. No solo las ha pagado la Fábrica sino también han contribuido algunos fieles. Se ha reintegrado todo el dinero a excepción de cuatro mil treinta y dos reales. ${ }^{57} \mathrm{De}$ bronce igualmente hacen dos blandones grandes para el presbiterio. Ordenan trabajarlos el 2 de agosto de 1830 y los pagan de los atrasos de la mensa canonical. ${ }^{58}$

Pocas noticias más refieren piezas pagadas por la Seo. El 15 de junio de 1896 autorizan al fabriquero dorar algunos cálices cuya copa está inservible. ${ }^{59} \mathrm{El} 10$ de diciembre de 1902 advierten que ha desaparecido el puntero de plata que sirve al prelado $^{60}$ y cinco días más tarde el cabildo manda ha-

\footnotetext{
47 "Tenemos nosotros unas andas de plata que valen más que toda la catedral de Toledo". Cfr. LLORENTE FALCÓ, Teodoro. De mi Valencia de otros tiempos. Memorias de un setentón. Valencia: Federico Doménech, S. A., 2001, vol. II, pp. 343-344.

${ }^{48}$ ACV. Leg. 314. Libro de Deliberaciones. 1787, ff. 168v-169. SANCHIS SIVERA, José, 1909 (nota 4), p. 415.

49 COTS MORATÓ, Francisco de Paula, 2007 (nota 8), p. 82.

50 ACV. Leg. 319. Libro de Deliberaciones. 1792, f. 2v. SANCHIS SIVERA, José, 1909 (nota 4), p. 409.

${ }^{51}$ ACV. Leg. 339. Libro de Deliberaciones. 1812, f. 144. LLORENS RAGA, Peregrín-Luis. Relicario de la catedral de Valencia. Valencia: Institución Alfonso el Magnánimo-Diputación de Valencia-Caja de Ahorros y Monte de Piedad de Valencia, 1964, p. 92.

52 ACV. Leg. 343. Libro de Deliberaciones. 1816, f. 2.

53 En 2016 fue limpiado en el IVACOR y comprobaron que la camisita es de seda natural, sin costuras, y tejida en el siglo XIV.

${ }^{54}$ ACV. Leg. 353. Libro de Deliberaciones. 1826, f. 60v.

55 ACV. Leg. 356. Libro de Deliberaciones. 1829, ff. 20-20v.

56 ACV. Leg. 356. Libro de Deliberaciones. 1829, f. 40.

57 ACV. Leg. 359. Libro de Deliberaciones. 1832, f. 12. Véase también COTS MORATó, Francisco de Paula, 2008 (nota 35), pp. 172-173.

58 ACV. Leg. 357. Libro de Deliberaciones. 1830, f. 41.

${ }^{59}$ ACV. Leg. 408. Libro de Deliberaciones. 1895-1897, f. 74.

60 ACV. Leg. 410. Libro de Deliberaciones. 1901-1903, f. 120v.
} 
cer uno nuevo. ${ }^{61}$ Finalmente, el 15 de julio de 1912, otorgan poder al fabriquero para gastar hasta trescientas pesetas o invertir la plata deforme en el arreglo de tres incensarios. ${ }^{62}$

\section{Donaciones a la Seo}

Si antes hemos referido las obras que el cabildo o la Fábrica costean para el servicio de la metropolitana, en este punto veremos las donaciones que reciben. Existen bastantes dádivas por parte de algunos capitulares y fieles devotos pues, debido a la fundición en Palma de Mallorca en 1812 y a la de Valencia de 1823, hay que reponer relicarios así como otros enseres del templo necesarios para las prácticas del culto y de la devoción.

El 16 de diciembre de 1776, el canónigo Josep Blanch entrega al cabildo una carta y varias joyas. Entre estas había dos cruces: una de diamantes y esmeraldas -tasada en quinientos escudos romanos- y la otra de oro, con cuarenta baiocos -tasada en otros veintitrés escudos romanos-. También había una sortija de oro con una esmeralda guarnecida de diamantes - de valor de doscientos escudos romanos- y otra con una imagen de la Virgen con diamantes -cincuenta y cinco escudos romanos-. Todo proviene del pontifical del arzobispo Tomás de Azpuru (1713-1772). Estas alhajas Ilegan a la metropolitana en virtud de la Real Orden de 15 de mayo de 1756 que manda que de los pontificales de los obispos fallecidos el colector general elija una. ${ }^{63}$ El 8 de enero del año siguiente, el cabildo escoge la sortija de una esmeralda con diamantes. ${ }^{64}$

Pero la abundancia de donaciones se refleja en dos tipologías de orfebrería: vasos eucarísticos y relicarios. En cuanto a los primeros indicamos que el 29 de marzo de 1779 el canónigo Luis Adell y Ferragut (1760-1779) regala una custodia de oro "puríssimo", de setenta onzas y siete adarmes de peso para que el cabildo disponga su uso para la catedral. Le dan las gracias y celebran una misa por el donante. ${ }^{65}$ Otro viril, que provenía del extinguido monasterio de la Valldigna, entra el 8 de enero de $1821 . .^{66} \mathrm{El}$ cardenal Giacomo Giustiniani (1769-1843), nuncio del papa en España y canónigo de la catedral, hace llegar una custodia en vermeil hecha en París. De esta da cuenta una carta del prelado a los capitulares ${ }^{67}$ y, el 15 del mismo mes, Luis Lasala (1802-1828) presenta el viril al cabildo. "Y visto por su ylustrísima la preciosidad y mérito de esta alhaja", acordaron decirle que fue de su gusto y le dieron las gracias. ${ }^{68}$ Mucho tiempo después no debió ser una pieza muy valorada, pues, en el Cabildo ordinario del 2 de diciembre de 1882, examinan el modelo de una custodia que quiere regalar un bienhechor. Para realizarla utilizarán la Custodia del Corpus y la del cardenal Giustiniani "que hoy no se usa". Nombran al deán y al arcediano para que hablen con el arzobispo sobre si conviene. ${ }^{69}$ No debió de hacerse, pues no hemos visto que las noticias al respecto continúen. Todas estas obras que hemos referido ya no están en la Seo.

Los cálices son un vaso del que tenemos numerosas referencias. El 1 de agosto de 1783 presentan uno de plata "labrado y sobredorado" así como un breviario donación del canónigo García de los Herreros (1760-1792). Deciden que el cáliz sirva para las misas canonicales y el breviario en el coro los días que el cabildo determine. Lo pasan todo a la sacristía. ${ }^{70}$ El 9 de septiembre de 1786 el canónigo Carrillo y Mayoral regala un cáliz con su patena "de oro, guarnecido de piedras preciosas". Junto a él hay una bolsa de los corporales, cubre cáliz, casulla, manípulo y capa pluvial "de tela de tisú de oro y plata con galones de oro", amito, alba, cíngulo. ${ }^{71}$ El cáliz se conserva y no es de oro sino de plata dorada. Tampoco lo adornan piedras preciosas sino cristales de colores (fig. 3). Es una pieza bellísima labrada por el platero valenciano Josep Bellmont (1713-1787) entre junio de 1783 y junio de 1784, pues autor y marcador son el mismo. Fue este un ejercicio en que el maestro era

\footnotetext{
${ }^{61}$ ACV. Leg. 410. Libro de Deliberaciones. 1901-1903, ff. 121-121v.

62 ACV. Leg. 413. Libro de Deliberaciones. 1910-1912, f. 93v.

${ }^{63}$ ACV. Leg. 303. Libro de Deliberaciones. 1775-1776, ff. 230v-231v.

${ }^{64}$ ACV. Leg. 404. Libro de Deliberaciones. 1777, ff. 2 v.-3.

65 ACV. Leg. 306. Libro de Deliberaciones. 1779, f. 49v. y ff. 56v.-57.

${ }^{66}$ ACV. Leg. 348. Libro de Deliberaciones. 1821, f. $3 \mathrm{v}$.

67 ACV. Leg. 354. Libro de Deliberaciones. 1827, f. 11.

${ }^{68}$ ACV. Leg. 354. Libro de Deliberaciones. 1827, f. 13v.

69 ACV. Leg. 403. Libro de Deliberaciones. 1880-1882, f. 144v.

70 ACV. Leg. 310. Libro de Deliberaciones. 1783, ff. 57v.-58.

71 ACV. Leg. 313. Libro de Deliberaciones. 1786, ff. 115v.-116
} 
mayoral primero del Colegio de Plateros y, por tanto, también marcador. ${ }^{72}$

Las donaciones de Carrillo y Mayoral no terminan aquí. Después de su fallecimiento entran algunas más. En el Cabildo del 15 de diciembre de 1815 ven una cortina para el altar de la Purísima, una tarima para colocar la reliquia e imagen de la Virgen en el Altar Mayor en sus festividades y un cáliz con su patena en obsequio a María Santísima. ${ }^{73}$

Durante los siglos XIX y XX advertimos más donaciones de cálices aunque algunos deben de haberse perdido. En el Cabildo del 1 de junio de 1847 leen un oficio del pavorde José Matres (18471873) quien ofrece un cáliz, del que no indican las características. ${ }^{74}$ Tiempo después, el 1 de septiembre de 1860, entran un cáliz de plata sobredorada y copa de oro, unas vinajeras con su campana y platillo, también de plata dorada, todo legado por el arzobispo Pablo García y Abella (17761860). ${ }^{75}$ Pero es el cardenal Sebastián Herrero y Espinosa de los Monteros (1822-1903) quien deja muchas de sus pertenencias. En el Cabildo del 15 de diciembre de 1903, pocos días después de su fallecimiento, entran el alba, amito, casulla y cáliz dorado que algunas asociaciones piadosas de la Diócesis le regalaron con motivo del vigesimoquinto aniversario de su pontificado. ${ }^{76} \mathrm{El}$ cáliz y la patena se conservan en la sacristía y el Inventario de 1907 lo refiere como "Un estuche con cáliz, patena y cucharilla de plata, regalo del cardenal Herrero". Al lado la crucecita a lápiz indica que lo han recuperado después de la Guerra Civil. Estaba en el Departamento de Caudales, cuarto segundo, en un armario de madera. ${ }^{77}$ Es de plata dorada, con algunos diamantes, ${ }^{78}$ y está marcado en el obrador de Miguel Orrico Larocca (1835-1908) (fig. 4). Mantiene un estilo anclado en el "gótico ideal" tan en boga en la segunda mitad del XIX y principios del XX. Con peana polilobulada presenta las armas del cardenal Herrero y se acompaña por microesculturas de Cristo, María y José, senta-

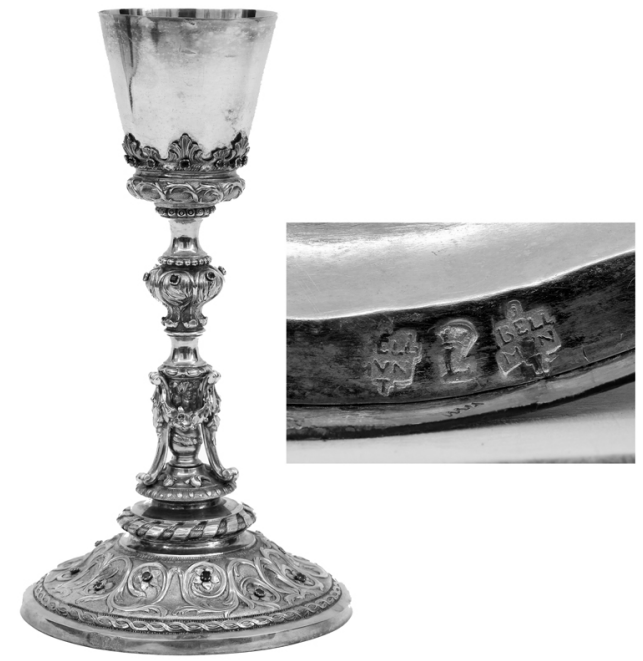

Fig. 3. Josep Bellmont. Cáliz. 1783/84. Foto A. Sáiz. (C) Archivo de la Catedral de Valencia.

dos y de cuerpo entero, al estilo de las piezas labradas en Francia e Italia durante el siglo XIX y principios del XX. El nudo muestra seis botones de esmaltes cloissone y tiene tondos con santos en la sotocopa.

Dos cálices más son donados antes de la Guerra Civil. En el Cabildo del 3 de noviembre de 1919 leen una carta del don Juan Fernández Limoner por la que entrega a la Fábrica un cáliz con servicio de patena y cucharilla que perteneció al arzobispo José Salvador y Barrera (1851-1919). ${ }^{79}$ El 1 de abril de 1928 D. Nicolás David regala "un artístico cáliz de plata dorado" como recuerdo de sus bodas de oro sacerdotales. ${ }^{80}$ Este último se conserva y muestra el "gótico ideal" muy modificado respecto al visto en el del cardenal Herrero, pero es mucho más sencillo.

Otro grupo de piezas donadas son las necesarias para el altar: blandones, candeleros, cruz, sacras y

72 COTS MORATÓ, Francisco de Paula. "A propósito de unos cálices de la catedral de Valencia". En: RIVAS CARMONA, J. (coor.). Estudios de Platería. Murcia: Publicaciones de la Universidad de Murcia, 2015, pp. 103-106.

73 ACV. Leg. 342. Libro de Deliberaciones. 1815, ff. 364v.-365.

74 ACV. Leg. 374. Libro de Deliberaciones. 1847, ff. 28-28v.

75 ACV. Leg. 387. Libro de Deliberaciones. 1860, ff. 41-41v.

76 ACV. Leg. 410. Libro de Deliberaciones. 1901-1903, f. 195.

77 ACV. Leg. 6065. Inventario de 1907, f. 45.

78 Para este cáliz véase TERESí DOMINGO, Germán. "Cáliz del cardenal Espinosa de los Monteros". En: BENITO DOMÉNECH, Fernando y SANCHO ANDREU, Jaime (com.). La Luz de las Imágenes. Áreas expositivas y análisis de obras. Valencia: Generalitat Valenciana, vol. II. 1999, p. 346. ficha $n^{\circ}$ 293. La fotografía, por error, está en la ficha $n^{\circ} 292$.

79 ACV. Leg. 415. Libro de Deliberaciones. 1916-1919, f. 163v. y OLMOS Y CANALDA, Elías, 1949 (nota 6), p. 371.

80 ACV. Leg. 418. Libro de Deliberaciones. 1928-1931, f. 14. 


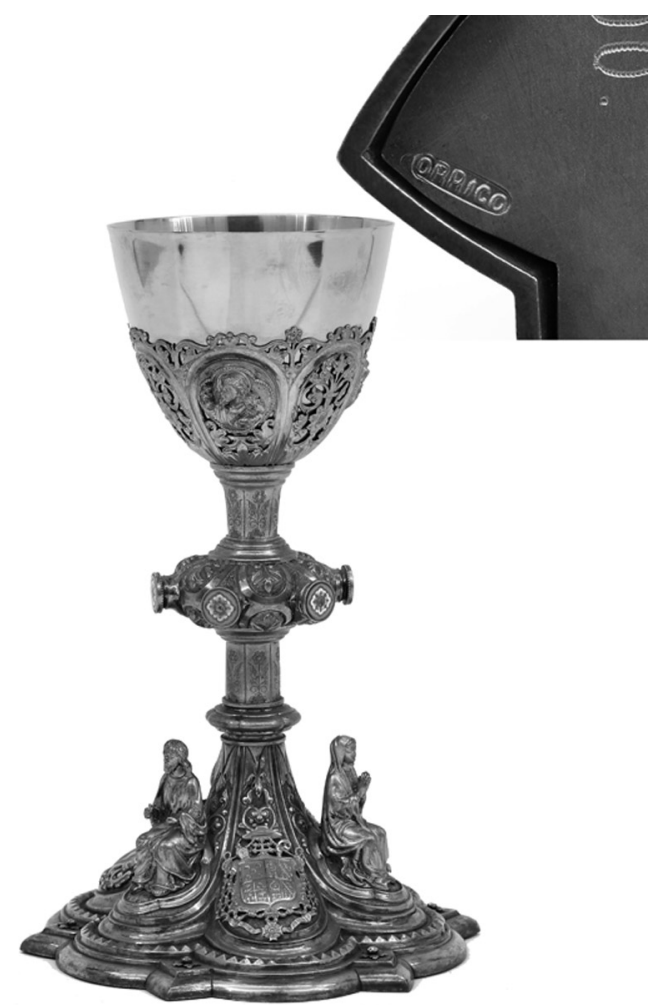

Fig. 4. Miguel Orrico Larocca. Cáliz. 1900. Foto A. Sáiz. (c) Archivo de la Catedral de Valencia.

lámparas. El 15 de febrero de 1785 el canónigo Manuel Navía (1777-1809) expone que un devoto quiere regalar doce blandones de plata para el Altar Mayor cuando exponen el Santísimo Sacramento. Al margen, el libro indica que el donante es el canónigo lectoral Joaquín Gibertó (17671796). ${ }^{81}$ En el Cabildo del 23 de mayo del mismo año Gibertó regala los blandones de plata. Los labró Bernat Quinzà, platero de la catedral. ${ }^{82}$ Años después, figuran en el listado que se hizo en 1811 y que permaneció en la catedral durante la Guerra del Francés (1808-1813). ${ }^{83}$ Sanchis Sivera refirió la donación acaecida en 1785, indicando que en su tiempo todavía existían. Publicó que pesaban mil cuatrocientas cuarenta y cinco onzas y dos adarmes y costaron dos mil seiscientos diecinueve libras y siete sueldos. ${ }^{84} \mathrm{El}$ canónigo-lectoral no se contenta con esta donación sino que, en 1791, ofrece una sacra para el Altar Mayor los días que celebran los capitulares. El coste de plata y hechuras es de quinientas sesenta y una libras.$^{85}$ Sanchis Sivera la nombra sin indicar el año de su entrega. ${ }^{86}$ No se conserva en la actualidad.

El 8 de junio de 1805 el canónigo Carrillo y Mayo$\mathrm{ral}$ regala cuatro candeleros de cristal de roca con cabos y pies de plata para el armario de las reliquias. Además, quiere que se bajen dos más que hay en la catedral del espolio del arzobispo Folch de Cardona (1657-1724), pues son "seis los que por antigua dispossición deben encenderse para su manifestación". ${ }^{87}$ El 2 de abril de 1832, los albaceas de otro canónigo, esta vez Miguel Zafra, regalan a la Fábrica "las alhajas de plata de su oratorio privado", sin especificar cuáles y cuántas son. ${ }^{88}$ Ya más tardíamente, en el Cabildo del 5 de febrero de 1876, el deán informa de que una persona devota ha ofrecido dos candeleros de plata para el altar de la Purísima. ${ }^{89}$ Tampoco estas donaciones existen a día de hoy.

Como ya se ha comentado, el bronce va ocupando su lugar en los altares de la Seo. El 1 de septiembre de 1825 el canónigo-magistral presenta "dos magníficos blandones de bronce". Los trabajó Antonio Blanco, broncista de Valencia. ${ }^{90} \mathrm{Al}$ año siguiente, en el Cabildo del 8 de agosto de 1826, el canónigo Luis Exarque (1814-1834) presenta otros dos para el presbiterio. ${ }^{91}$ En el Cabildo del 29 de mayo de 1888 indican que una persona piadosa regala una cruz de bronce dorada y plateada para

81 ACV. Leg. 312. Libro de Deliberaciones. 1785, ff. 12v.-13.

82 COTS MORATÓ, Francisco de Paula. "Plata perdida para siempre: el inventario de la catedral de Valencia de 1785". En: RIVAS CARMONA, J. (coor.). Estudios de Platería. Murcia: Publicaciones de la Universidad de Murcia, 2012, p. 149.

83 COTS MORATÓ, Francisco de Paula. "Piezas de platería de la catedral de Valencia desaparecidas durante la Guerra Civil española". Laboratorio de Arte, 2013, n² 25, Ap. Doc. I, p. 161.

84 SANCHIS SIVERA, José, 1909 (nota 4), p. 430.

85 ACV. Leg. 318. Libro de Deliberaciones. 1791, f. 107.

86 SANCHIS SIVERA, José, 1909 (nota 4), p. 438.

87 ACV. Leg. 332. Libro de Deliberaciones. 1805, ff. 86v.-87.

88 ACV. Leg. 359. Libro de Deliberaciones. 1832, ff. 17-17v.

${ }^{89}$ ACV. Leg. 400. Libro de Deliberaciones. 1875-1876, f. 86.

90 ACV. Leg. 352. Libro de Deliberaciones. 1825, f. $95 \mathrm{v}$.

91 ACV. Leg. 353. Libro de Deliberaciones. 1826, f. 62. 
el Altar Mayor los días que hay dosel..$^{92}$ Estas obras no están en la Seo.

Como ya hemos visto las lámparas de la catedral, otrora de plata, se reponen en bronce. En el Cabildo del 22 de marzo de 1825, leen una carta de don Luis Exarque en la que comunica, desde Madrid, que "remetía a su ylustrísima dos lámparas para el Altar Mayor de esta santa yglesia metropolitana para suplir a las que antes hubo". ${ }^{93}$ El 22 de diciembre de 1827 el beneficiado Tomás Rubio dona otra de bronce plateado para la capilla de Santo Tomás Apóstol. ${ }^{94}$ Las lámparas desaparecieron en la Guerra Civil.

En cuanto a las donaciones de la primera mitad del siglo XX, la más importante es la del cardenal Herrero, fallecido el 9 de diciembre de 1903. Fue él quien legó más objetos para el culto. Los canónigos gastaron 25.722 pesetas de su fondo. El 1 de febrero de 1904 entran veinte juegos de candeleros con veinte cruces grandes, ocho atriles y seis juegos de sacras grandes. Además, catorce juegos completos de manteles para el Trasagrario y los altares de la Purísima y Santo Tomás de Villanueva. Unos meses más tarde, el 1 de octubre, llegaron a la Fábrica una docena de candeleros de plata, dos candelabros de tres luces, una escultura de plata blanca que figura el Descendimiento de la Cruz y un jarrón, también todo de plata. ${ }^{95}$ Algunas de estas obras, como el Descendimiento o las puertas del Sagrario, permanecen en la catedral. Estas últimas son las más recordadas. El Sagrario antiguamente estaba en el Trascoro y hoy se utiliza para el Monumento del Jueves y Viernes Santos al perderse la Urna (Atribuida a Lluís Puig, 1630) en julio de 1936. El cardenal Herrero heredó plata de su familia, plata que fundida sirvió para las citadas puertas. ${ }^{96}$ En el Cabildo del 15 de noviembre de 1905 un canónigo "pidió permiso para que una persona debota pudiera hacer las puertas del Sagrario de plata". Los capitulares acceden y dan "con anticipación las gracias a este bienhechor". ${ }^{97}$ Ello indica que la plata del cardenal fue fundida con los do-

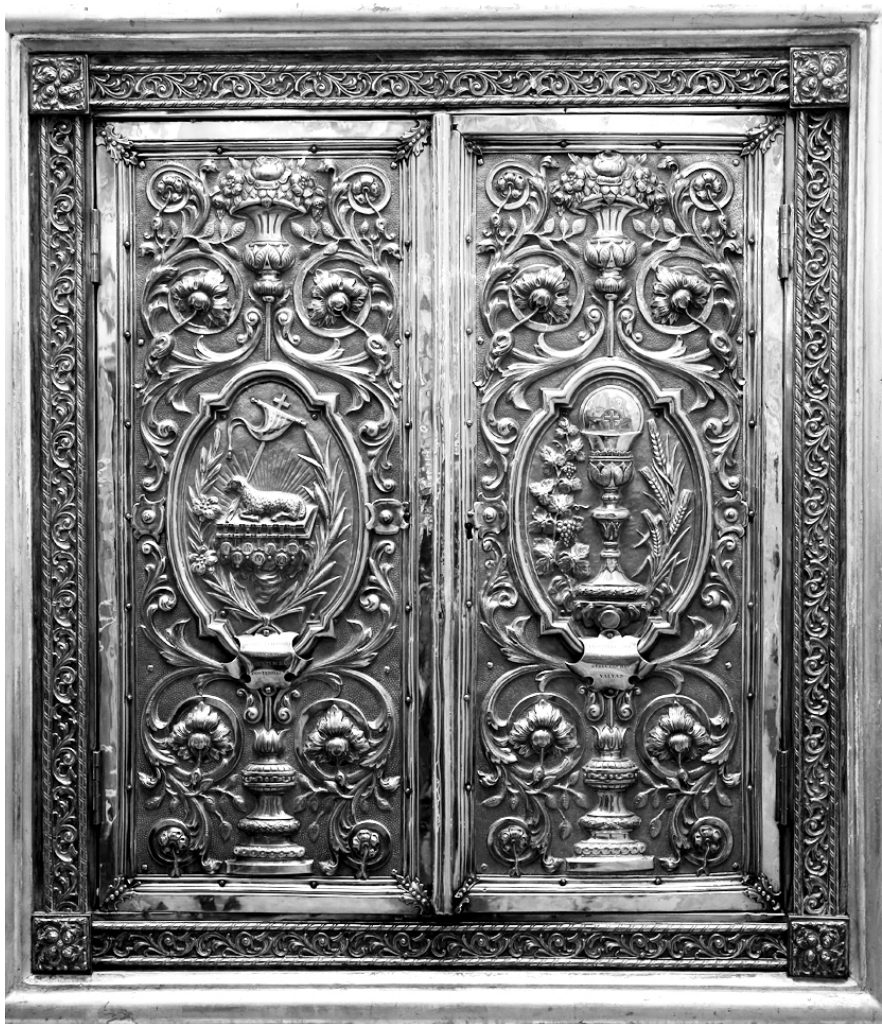

Fig. 5. ¿Miguel Orrico Larocca? Puertas de Sagrario. 1905. Foto A. Sáiz. (c) Archivo de la Catedral de Valencia.

nativos de esa "persona debota". El Inventario de 1907 ya las recoge: "Dos puertas de plata, que cierran el Sagrario, regalo del cardenal Herrero". Al lado hay una crucecita a lápiz que indica que se han recuperado después de la contienda civil.98 González Martí escribió que después de la guerra, en el antiguo convento del Carmen, entonces Museo de Bellas Artes, estaban "las andas de plata y el tabernáculo de la Catedral de Valencia, maltrechos y mutilados". 99 Seguramente el tabernáculo sería el sagrario al que nos referimos, cuyas puertas volvieron a la catedral.

Estas son planchas de plata blanca adheridas a una base de madera (fig. 5). Tienen una decoración, en cincelado y repujado, que forma flores giradas, urnas y jarros de flores. Las flores de las

\footnotetext{
92 ACV. Leg. 405. Libro de Deliberaciones. 1886-1888, f. 121.

${ }^{93}$ ACV. Leg. 352. Libro de Deliberaciones. 1825, ff. 34-34v.

94 ACV. Leg. 354. Libro de Deliberaciones. 1827, f. 89v.

95 ACV. Leg. 411. Libro de Deliberaciones. 1904-1906, ff. 12, 87v. y $46 \mathrm{v} .47$.

96 OLMOS Y CANALDA, Elías, 1949 (nota 6), p. 338

97 ACV. Leg. 411. Libro de Deliberaciones. 1904-1906, f. 104.

98 ACV. Leg. 6065. Inventario de 1907, f. 67. También en la parte final figuran como recuperadas, al igual que el cáliz donado por Herrero. Cfr. Apéndice n 8, f. 164.

${ }^{99}$ GONZÁLEZ MARTí, Manuel. "Mis actividades en el Museo Provincial de Bellas Artes. El edificio del Carmen". Levante. Suplemento dedicado a sus hombres, a su historia y a su tiempo. № 295. Valencia, 24 de noviembre de 1961, p. 4.
} 
puertas siguen el modelo de los roleos de la segunda mitad del siglo XIX -friso del altar de la Purísima de Santa María de Oliva- así como motivos que ya aparecen la primera mitad de esa centuria sobre el dintel de las puertas del comedor de gala de Buckingham Palace y más tarde en el palio negro de Juan Manuel Rodríguez Ojeda para la Hermandad de la Macarena, bordado entre 1890 y 1891. Más cercano a ellas están los roleos del antiguo manto procesional de la Virgen de los Dolores de la Iglesia de Santa María de Oliva del primer cuarto del siglo XX. Todos los motivos decorativos de las puertas están en consonancia con lo que se labraba y bordaba en la Valencia de la época. El lenguaje icónico es salvífico y eucarístico. En el anverso tiene, la primera de las puertas, el Cordero Apocalíptico sobre el Libro de los siete sellos, cada uno de estos numerados en romanos, envuelto en una mandorla. La mitad de ella es de flores, la otra mitad son juncos con sus capullos. Debajo una inscripción en latín en capitales: PIETATIS CLARISSIMI / PRAESUS / MONUMENTUM HABE / POSTERITAS. En la segunda puerta la mandorla está formada por ramas y hojas de parra y espigas de trigo. Dentro está el cáliz con la hostia consagrada. Debajo: EX SUPELLECTILE / EMI. CARD. HERRERO / STRUCTAS HAS / VALUAS. En el reverso de cada una de ellas están los mismos motivos de flores enroscadas y, en el centro, dos cruces latinas doradas. La de la primera puerta lleva engastada una amatista en el crucero.

La iconografía de las puertas alude al Cristo, cuyo cuerpo transmutado se guarda en el sagrario. Cuando nació Jesús el mundo estaba perdido y de ahí las flores, símbolo indudable de la primavera y renovación que trae con él. Los juncos, en cambio, apuntan al Antiguo Testamento. ${ }^{100}$ Uno de los considerados precursores de Jesús, Moisés, fue dejado en una cesta de papiro y encontrado en el río junto a los juncos (Ex 2, 1-7). Ferguson nos dice que, de ahí, "los juncos se identifican con el lugar de donde proviene la salvación". ${ }^{101}$ La otra puerta figura la eucaristía, símbolo de la Nueva Ley, con el pan, representado por las espigas de trigo, y el vino, por las hojas de parra. La importancia del mensaje redentor viene remarcada por el Cordero. Él es quien es digno de abrir los siete sellos del Libro porque ha sido degollado por la Humanidad (Ap. 5, 1-14): Es el amor a muerte que da la vida y vence al pecado (Jn 15, 13). ${ }^{102}$

Sobre el autor de las puertas de momento no sabemos nada. No hemos advertido marcas en ellas. Puede que fuera el obrador de Miguel Orrico Laroca, el mejor de la ciudad en aquel momento, y que, en ocasiones, había trabajado para la Seo. En uno de sus catálogos, figuran dos puertas de sagrario que muestran alguna similitud con las que tratamos. Estas forman dos planchas de plata de medio punto y una tiene la custodia mientras que la otra el Cordero Apocalíptico. Los roleos no son tan claros y están adornadas por numerosos cristales de colores engastados. ${ }^{103}$ Posiblemente las del catálogo sean de una cronología posterior.

El orfebre Miguel Orrico Larocca era napolitano y nació en Trechinna, provincia de Potenza, en el reino de Nápoles, hacia 1835. Después de trabajar en las comarcas del Maestrat y Els Ports, se estableció en Valencia. Falleció en esta ciudad el 25 de junio de 1908, en la parroquia de San Bartolomé, ${ }^{104}$ y fue enterrado en el cementerio municipal de Valencia al día siguiente. ${ }^{105} \mathrm{Su}$ obrador fue el más afamado de su tiempo siendo continuado por tres generaciones, todos descendientes suyos, Ilamados Manuel.

Otra donación posterior a las del cardenal Herrero tiene lugar en 1915. En el Cabildo del 15 de mayo exponen que el canónigo Sr. Barbarrós Moner (1877-1915) deja 15.299 pesetas en valores o bonos para completar la candelería del Altar Mayor. ${ }^{106}$ En el Cabildo del 1 de febrero de 1916 indi-

\footnotetext{
100 A pesar de este simbolismo tan marcado, los juncos y las espigas eran también un ornamento de las Artes Decorativas en 1905. Una diadema encargada ese año por el conde Louis de Clermont-Tonnere a Chaumet los muestra juntos, al igual que otra del año anterior. Cfr. LOYRETTE, Henri (dir.). Chaumet. Joaillier parisien depuis 1780. París: Flammarion, 2017, p. 311.

101 FERGUSON, George. Signos y símbolos en el arte cristiano. Buenos Aires: Emecé Editores, 1956, p. 35. Este autor también indica la identificación de los juncos con los fieles y la Iglesia, tomando la cita de Job 8, 11 "¿Brota el papiro fuera de la marisma? ¿Crece el junco fuera del agua?".

102 "Nadie tiene mayor amor / que el que da su vida por sus amigos".

${ }^{103}$ Archivo Javier Sánchez Portas. "Plata Orrico. Registrada N 50800. Valencia (España)". (Catálogo), f. 173A.

104 La Correspondencia de Valencia. Año 31, n 10461. Valencia, jueves 25 de junio de 1908, p. 1. En COTS MORATÓ, Francisco de Paula, 2008 (nota 35), p. 178, damos erróneamente la fecha de su muerte. Agradezco a Javier Sánchez Portas el haber buscado conmigo esta información del fallecimiento de Miguel Orrico.

${ }^{105}$ Archivo del Cementerio General de Valencia. Libro 15 de mayo 1908-4 de junio 1909, f. 20v, 26 de junio de 1908.

106 ACV. Leg. 414. Libro de Deliberaciones. 1913-1915, f. 109v.
} 
can que han pagado seis candeleros de plata de ese dinero y todavía quedan 9.000 pesetas en bonos del Tesoro para misas. ${ }^{107}$ No hemos visto que estas piezas estén en la catedral.

Como antes hemos referido las donaciones de relicarios son muy frecuentes. El 8 de febrero de 1781 entran una serie de dádivas del fallecido canónigo Alfonso Milán de Aragón, marqués de san José (1734-1781). Un Lignum Crucis en un relicario de filigrana ${ }^{108}$ con perfiles y flores doradas de media vara de alto. También dos casullas, dos albas y dos amitos. ${ }^{109}$ El 15 de septiembre de 1784 el cabildo "recibió la reliquia de una carta del señor san Vicente Ferrer con su marco de plata y cristal delante". La donó María Budino, viuda del teniente general Ignacio de Sala. ${ }^{110}$ Ambos se conservan y el de la carta es de factura simple. Sí es bellísimo el Relicario del Lignum Crucis regalado por este canónigo. Es pieza de filigrana de plata blanca que recuerda las obras romanas del periodo. La reliquia no está en la teca.

Una de las imágenes-relicario más apreciadas en la catedral era la de San Vicente Mártir, patrón de la ciudad y la Archidiócesis de Valencia. El 22 de enero de 1800 sale por primera vez en procesión. Fue donación póstuma del canónigo Francisco Pérez Bayer (1711-1794), ${ }^{111}$ preceptor de los infantes reales y obra del platero de la catedral Bernat Quinsà. El artífice la tenía por una de sus mejores creaciones. Desapareció en el incendio de la catedral acaecido el 21 de julio de 1936.

De 1818 constan varias donaciones. El 9 de abril D. Pedro Calvo (1809-1834), beneficiado de la Seo, "presentó un relicario de plata, que había costea- do de sus propios, para colocar en él la Santa Espina que regaló" san Luis, rey de Francia. ${ }^{112}$ Actualmente el Relicario de la Espina de san Luis, rey de Francia, es de la primera mitad del siglo XV y está marcado con la de Valencia. El único relicario con una espina al que puede referirse esta noticia por el momento, y a modo de hipótesis, es el de Jaume Castellá. Su pie es de estas fechas aunque perdió el nudo en la Guerra Civil. Esta pieza, muy rara debido a las múltiples adiciones que presenta, es una bellísima historia viva de la orfebrería con partes de los siglos medievales así como del XVI y XIX. ${ }^{113}$

En la Palabreta del 24 de septiembre el canónigo Luis Lasala "manifestó que movido de su devoción a santo Tomás de Villanueva, había mandado hacer a sus costas un busto del santo de plata, que se estava concluyendo, del que hacía donación al ylustrísimo cabildo". ${ }^{114}$ El busto reemplazaba otro del platero catalán Francesc Via de 1703. Sanchis Sivera informa de su donación e indica que estaba en una vitrina en la Capilla de las Reliquias en 1909. Lo ejecutó el platero Bellmonte, orfebre por el momento no identificado. ${ }^{115}$ Hoy está en el altar de su capilla.

En el Cabildo de 22 de diciembre de 1818 don Juan Bautista Pérez Caballero (1766-1820), ${ }^{116}$ canónigo-magistral, da un misal grande y un "relicario grande de plata con el objeto de que se colocase en él el pedazo de ramal con seis espinas de la corona del Señor". ${ }^{117}$ El 8 de enero de 1819 otros dos canónigos comunican a los capitulares que han colocado la reliquia en la pieza de plata. ${ }^{118}$ El relicario (fig. 6) lleva la marca de Vicent

107 ACV. Leg. 415. Libro de Deliberaciones. 1916-1919, f. 4v.

108 SANCHIS SIVERA, José, 1909 (nota 4), p. 418

109 ACV. Leg. 308. Libro de Deliberaciones. 1781, ff. $13 \mathrm{v}-14$.

110 ACV. Leg. 311. Libro de Deliberaciones. 1784, f. 165v. SANCHIS SIVERA, José, 1909 (nota 4), p. 413.

111 Véase COTS MORATÓ, Francisco de Paula. "José Esteve Bonet y la Purísima Concepción de la catedral (Notas sobre su iconografía en Valencia en la Edad Moderna". En: CALLADO ESTELA, E. (Ed.). De Rebus Ecclesiae. Valencia: Publicacions de I'Institució Alfons el Magnànim. Valencia, 2017, pp. 307-344. Aquí se estudian, entre otras obras, las donaciones del canónigo Francisco Pérez Bayer a la Seo.

112 ACV. Leg. 345. Libro de Deliberaciones. 1818, f. 99.

113 Para este relicario véase CASTELLÓ DOMÉNECH, Fernando. “El relicario medieval del caballero Jaume Castellà de la catedral de Valencia". En: RIVAS CARMONA, J. Estudios de Platería. Murcia: Publicaciones de la Universidad de Murcia, 2014, pp. 103-113. Con bibliografía.

114 ACV. Leg. 345. Libro de Deliberaciones. 1818, f. 215v.

115 SANCHIS SIVERA, José, 1909 (nota 4), p. 389. No hemos podido estudiar todavía por la dificultad de acceso los bustos de Santo Tomás de Villanueva y el de San Luis Obispo. En breve los bajarán de sus altares para limpiarlos.

116 ACV. Leg. 438. Libro de Oposiciones a canónigo magistral. 1813 y Leg. 440. Libro de Oposiciones a canónigo magistral. 1820. La cronología se toma de estos dos volúmenes

117 ACV. Leg. 345. Libro de Deliberaciones. 1818, f. 300. SANCHIS SIVERA, José, 1909 (nota 4), p. 420

118 ACV. Leg. 346. Libro de Deliberaciones. 1819, f. 4v. Fue limpiado en el IVACOR en 2015. 


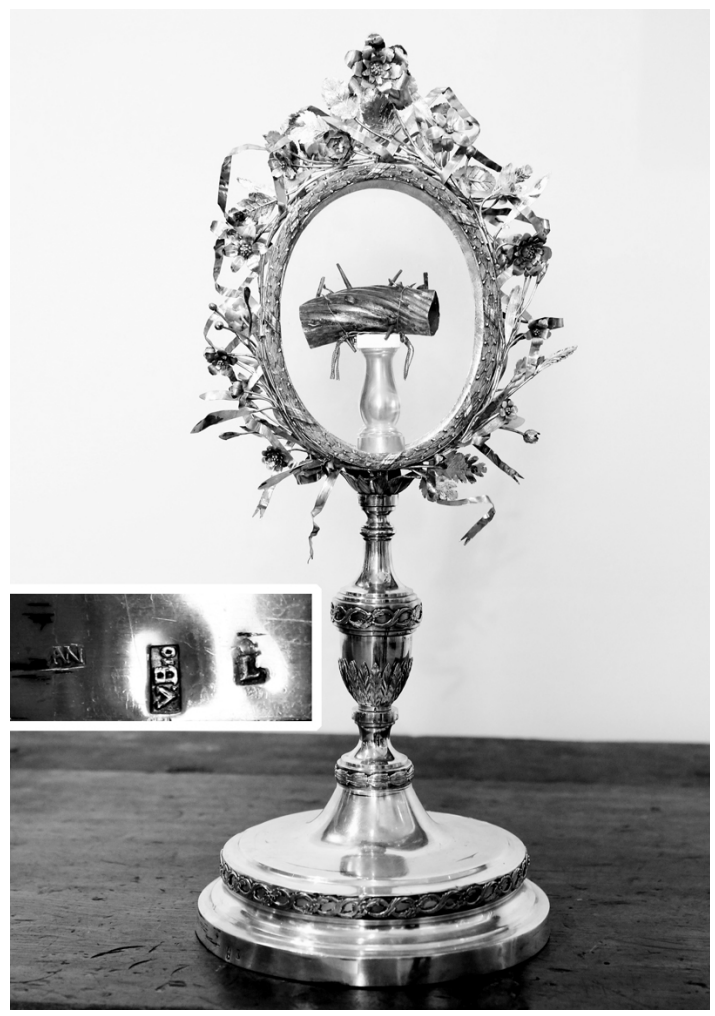

Fig. 6. ¿Josep Alemany? Relicario del ramal de espinas. 1818. Foto A. Sáiz. () Archivo de la Catedral de Valencia.

Broquer (1784-1834/35), ${ }^{119}$ maestro de oro de la Ciudad y Reino, que ese año es mayoral primero y, por tanto, marcador. ${ }^{120}$ La otra, del artífice, no está identificada. Es una "AÑ" que muestra el resto borrado ¿Quizás Josep Alemany (1816-1847)? ?121 Junto a ellos está la L coronada de Valencia. Es una pieza labrada en plata banca y con adornos de plata dorada. Descansa sobre una base redonda con una guirnalda de ochos entrelazados. Astil con nudo de jarrón y detalle de hojas de acanto doradas en la base de este. La parte superior, donde estaría el toro, se enriquece con otra tira de ochos. El expositor es oval y está rodeado por una guirnalda de cintas y flores de carácter naturalista. El interior conserva el ramal dorado gótico de las seis espinas. Esta pieza está formalmente dentro del clasicismo que impera en Valencia durante el primer tercio del siglo XIX. Las flores que la de-

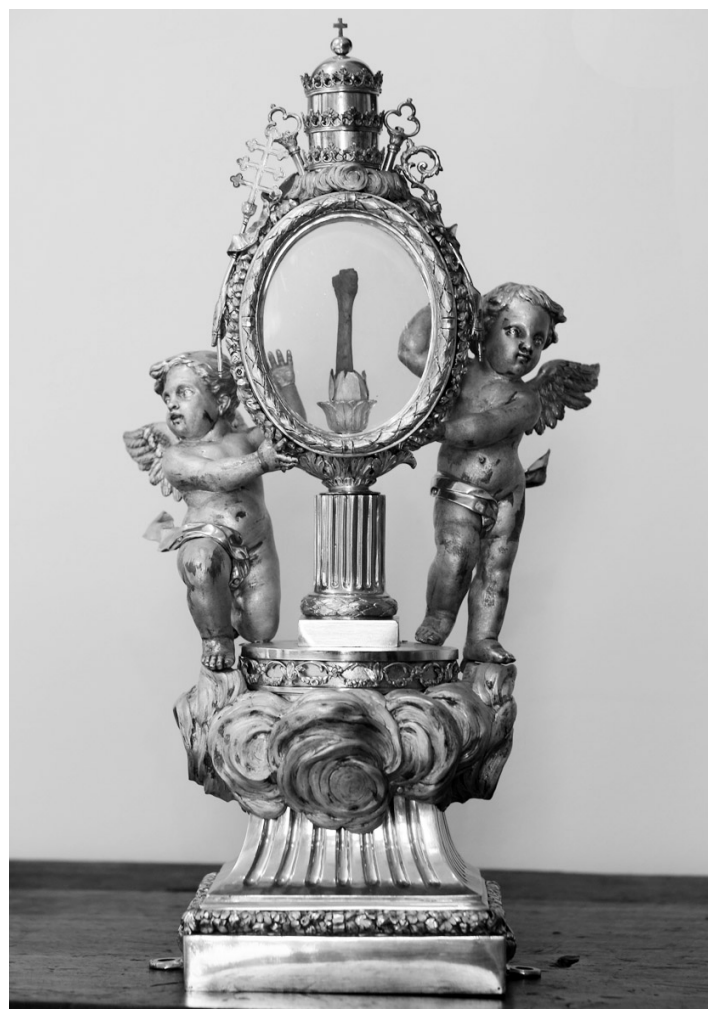

Fig. 7. ¿José Carlos Quinzà? Relicario de san Gregorio. 1825 Foto A. Sáiz. ( ) Archivo de la Catedral de Valencia.

coran están estrechamente relacionadas con el Relicario de los Santos y Beatos Jesuitas de 1827.

Otros dos relicarios son de la década de 1820 . En el Cabildo del 8 de noviembre de 1819 don Gregorio Joaquín Piquer dice que ha solicitado una reliquia de san Gregorio papa a Roma. La regala al cabildo y les pide permiso para hacer un relicario "decente, a fin de que pudiera llevarse en andas en la procesión", lo que se acepta. ${ }^{122} \mathrm{En}$ el Cabildo del 15 de julio de 1825 el albacea del señor Piquer "presentó un relicario de plata para colocar la reliquia de san Gregorio", que queda admitido. ${ }^{123}$ Este se conserva (fig. 7) y tiene base cuadrada con cuatro orificios para asirlo a las andas. Sobre ella hay una gran nube donde reposa la columna que sustenta el expositor flanqueado por dos ángeles. Lo rematan las armas papales con la

119 Cfr. TRAVER BADENES, Inmaculada (coor.). El Relicario de la catedral. Valencia: Generalitat Valenciana y CEU Universidad Cardenal Herrera, 2016. s/p.

120 COTS MORATÓ, Francisco de Paula. Los plateros valencianos en la Edad Moderna (siglos XVI-XIX). Repertorio biográfico. Valencia: Publicacions de la Universitat de València, 2005, p. 188.

121 Fernando Castelló Doménech está pendiente de la publicación de un artículo en el que llega a la misma conclusión.

122 ACV. Leg. 346. Libro de Deliberaciones. 1819, ff. 166-166v.

123 ACV. Leg. 352. Libro de Deliberaciones. 1825, ff. 83-83v. SANCHIS SIVERA, José, 1909 (nota 4), p. 407, informa de la donación de 1825. El relicario fue limpiado en el IVACOR en 2015. Cfr. TRAVER BADENES, Inmaculada, 2016 (nota 117). s/p. 
tiara, las dos llaves y la cruz de tres brazos. Como en el anterior comparte el doble cromatismo de plata blanca y plata dorada. El relicario, una bella obra de orfebrería, participa de la tradición valenciana del setecientos con los ángeles desnudos frecuentes en custodias y urnas. La decoración de ochos entrelazados, acantos y la columna estriada lo entroncan con las piezas clasicistas del momento en que se labra.

El 15 de enero de 1827 el canónigo Manuel Roa (†1842) "presentó un relicario que contenía reliquias" de varios santos y beatos de la Compañía de Jesús. Son las de Ignacio de Loyola, Francisco Javier, Estanislao de Kostka, Luis Gonzaga y Francisco Jerónimo. Estaban "todas en una plancha sostenida por un ángel, que descansaba sobre un pie obalado de plata y, en el remate, del relicario el Santísimo Nombre de Jesús". Fue legado del difunto beneficiado de la catedral Enrique Bellán. ${ }^{124}$ Sanchis Sivera informa de la donación, pero indica que es regalo de Manuel Roa. ${ }^{125}$ Esta pieza, de buen tamaño, es de plata blanca y no hemos advertido marcas en ella. Sin embargo, debe de ser obra valenciana por sus características formales y técnicas. Sobre una base de dos cuerpos está el nudo cósmico y, encima de él, un querubín desnudo sostiene con los brazos abiertos la placa rectangular con los tondos de las reliquias. La rematan dos tiras de flores de plata, del mismo estilo que las que tenían algunas diademas del ochocientos, ya vistas en el relicario de las seis espinas. Estas guirnaldas adornan el tondo calado con el Anagrama de Jesús y caen por los lados del expositor. El astil, con el ángel sustentador, proviene de las custodias salmantinas de fines del siglo XVII y XVIII, que fueron un tipo muy copiado, mientras que el Cosmos con nubes era habitual en las custodias y cruces valencianas del Rococó, derivado, a su vez, del reino de las Dos Sicilias.

Es muy curioso que la mayoría de estos relicarios no estén marcados. Además, muchos de ellos exhiben una fuerte relación entre factura, decoración y cromatismo que alude posiblemente a un mismo obrador. Quizá sean obra de José Carlos
Quinzà, que era el platero de la catedral en esos años. Del obrador de este artífice tenemos pocas noticias -suya es Custodia de la Asunción de Cocentaina (El Comtat), de 1805-, pero es muy posible que, siendo todas donaciones de clérigos vinculados a la Seo, estos encargaran las piezas a un platero de confianza. De la misma manera, la ausencia de marcas apunta igualmente a un orfebre conocido por los comitentes, como podía ser el mismo Quinzà. Esta idea viene reforzada porque cuando Joaquín Gibertó regala los blandones, los labra el platero de la Seo Bernat Quinzà, padre de José Carlos.

Otro gran busto entra en el relicario en 1831 para sustituir el perdido en 1812. El 15 de agosto el canónigo Luis Exarque regala uno "de medio cuerpo de plata de san Luis Obispo, para que pudiera colocarse en él la insigne reliquia de su cabeza". ${ }^{126}$ Sanchis Sivera hace saber que, el día siguiente a su entrega, colocaron la reliquia en la escultura de plata. ${ }^{127}$

En el Cabildo del 30 de abril de 1849 el vicario general capitular presenta "una preciosa paz de plata sobredorada que, según noticias, había pertenecido al Real Monasterio de San Miguel de los Reyes y se había entregado mediante sigilo natural para que no se extraviara". También ofrece un relicario del beato Ribera y otro del beato Hibernón "sobre pies de plata de hechura moderna y buen gusto, pero de poco peso". Acuerdan se incorporen al Relicario. ${ }^{128}$ No hemos visto la paz en la catedral.

A la segunda mitad del siglo XIX corresponden otros cuatro relicarios. En el Cabildo del 29 de mayo de 1861 el canónigo José Matrés presenta "tres relicarios de plata" para las reliquias de los santos José, Pedro Pascual y Roque. Las dos primeras están en la catedral y la tercera hay que pedirla. ${ }^{129}$ Sanchis Sivera informa de los santos José y Pedro Pascual. ${ }^{130}$ En el Cabildo de 6 de febrero de 1879 hay una donación póstuma de don Bernardo María, también perteneciente a la Seo. Entre otros obsequios ofrece una casulla con ramos y galones

\footnotetext{
124 ACV. Leg. 354. Libro de Deliberaciones. 1827, ff. 5-5v. Fue limpiado por el IVACOR en 2015.

125 SANCHIS SIVERA, José, 1909 (nota 4), p. 402.

126 ACV. Leg. 358. Libro de Deliberaciones. 1831, ff. 46-46v. Véase también la nota cosida entre los folios 45 y 46.

127 SANCHIS SIVERA, José, 1909 (nota 4), p. 390.

128 ACV. Leg. 376. Libro de Deliberaciones. 1849, f. 23v.

129 ACV. Leg. 388. Libro de Deliberaciones. 1861, ff. 40-40v. Años antes, José Matrés, en el Cabildo del 22 de abril de 1848, regala una araña de cristal magnífica que se pone en el Monumento, pues es Miércoles Santo. Cfr. ACV. Sig. 375. Libro de Deliberaciones. 1848 , ff. 16v-17

130 SANCHIS SIVERA, José, 1909 (nota 4), pp. 396 y 405.
} 
de oro y "un relicario de metal blanco con adornos de plata $y$, en él, una reliquia de san Bernardo". ${ }^{131}$

Unas pocas joyas son ofrecidas durante la segunda mitad del ochocientos a dos imágenes de devoción. En la Palabreta del 7 de febrero de 1868 leen una carta del albacea de doña Ana Pover de Ferraz quien lega unos pendientes de brillantes para la Virgen de Portaceli, del Altar Mayor. ${ }^{132}$ Están referidos en el Inventario de 1907 como que los lleva la imagen: "Dos pendientes de oro con doce brillantes cada uno". ${ }^{133}$ De finales de la centuria son dos regalos para la famosa Purísima (1781) del escultor José Esteve Bonet (1741-1802). El 10 de agosto de 1892, el arcipreste "presentó una preciosa pulsera de oro con una inscripción de brillantes que dice Tota Pulchra, donativo de una persona devota hacia la Purísima Concepción". ${ }^{134}$ También figura en 1907 en la misma imagen. ${ }^{135}$ En el Cabildo del 1 de marzo de 1897 el deán muestra otra manilla "de oro con algunas piedras" regalo de $D^{a}$. Luisa Sanmartín y Moya, igualmente para la imagen de la Inmaculada. ${ }^{136}$ Todas estas joyas han desaparecido.

No solo las imágenes más queridas suscitaban devoción y donativos. También lo hacía el Santo Cáliz. En el Cabildo del 15 de diciembre de 1903 exponen una instancia de $D^{a}$ Francisca Vidal y Montenegro, natural de Ibi (L'Alcoià) donde solicita "la correspondiente autorización para engarzar en la reliquia del Santo Cáliz una joya de su propiedad". El cabildo no acepta el ofrecimiento "por no poner la sagrada reliquia en manos de artistas, lo cual podría traer algún inconveniente". ${ }^{137}$

Independientemente de las donaciones necesarias para el sacrificio de la misa o la veneración de los santos, hay otros ofrecimientos precisos para la vi- da de la Metropolitana. De ella consta que, en el Cabildo del 1 de marzo de 1802, el Dr. Vicente Sanjuán regala "quatro vasos de plata, doradas sus copas, colocados uno dentro de otro en una caxita aforrada y guarnecida". Servirán para los trastes canonicales, para recibir las abluciones en las misas de Navidad y conmemoración de difuntos. ${ }^{138}$ Unos años después, en el Cabildo de 1 de agosto de 1829, exponen que el chantre de la Seo regala "unas andas o custodia plateada de buen gusto, construidas en esta ciudad", ${ }^{139}$ sin que den más detalles y finalmente, el 9 de diciembre de 1830, entran en la Fábrica veintisiete varas "glazé de plata" del legado del fallecido canónigo lectoral Romero. ${ }^{140}$ Todas estas piezas no se conservan en la Seo.

\section{Regalos del cabildo a otras personas o instituciones}

No son muy abundantes este tipo de noticias, apenas unas pocas. Las Actas Capitulares muestran cómo los canónigos ofrecen dádivas a otras personas o instituciones. De esta manera leemos que el 17 de agosto de 1813 acuerdan regalar al Real Colegio de Corpus Christi de Valencia el báculo dorado que usaba el arzobispo Fray Joaquín Company (1732-1813) "para que se coloque junto al cuerpo del beato señor patriarca". ${ }^{141}$

La mayoría de estos regalos son para canónigos de la Metropolitana que han sido preconizados a sedes episcopales. Así, en el Cabildo del 22 de febrero de 1862, muestran los objetos que ofrecen al nuevo obispo auxiliar de Sevilla Calixto Castrillo y Ornedo (1804-1869). Este era canónigo-tesorero y más tarde accedió a la sede de León. Son: un báculo de plata dorada, un anillo de amatistas con un topacio guarnecido de diamantes y una bandeja de plata con asas. ${ }^{142}$ Muchos años después, en la Palabreta del 7 de marzo de 1870, la

131 ACV. Leg. 402. Libro de Deliberaciones. 1878-1879, ff. 102v.-103.

132 ACV. Leg. 395. Libro de Deliberaciones. 1868, ff. 5-6. SANCHIS SIVERA, José, 1909 (nota 4), p. 176.

133 ACV. Leg. 6065. Inventario de 1907, f. 65.

134 ACV. Leg. 407. Libro de Deliberaciones. 1892-1894, f. 26v.

135 ACV. Leg. 6065. Inventario de 1907, f. 94. Muchas de estas joyas que llevaba la imagen fueron robadas en 1932, cuando los ladrones también la rompieron en muchos pedazos.

136 ACV. Leg. 408. Libro de Deliberaciones. 1895-1897, ff. 107v.-108.

137 ACV. Leg. 410. Libro de Deliberaciones. 1901-1903, f. 182

138 ACV. Leg. 329. Libro de Deliberaciones. 1802, ff. 31-31v.

139 ACV. Leg. 356. Libro de Deliberaciones. 1829, ff. 46-46v.

140 ACV. Leg. 357. Libro de Deliberaciones. 1830, f. 63v

141 ACV. Leg. 340. Libro de Deliberaciones. 1813, ff. 257-257v.

142 ACV. Leg. 389. Libro de Deliberaciones. 1862, f. 10v. 
hermana del fallecido monseñor Castrillo los devuelve a los capitulares. ${ }^{143}$ El mismo 22 de febrero de 1682 el cabildo decide regalar al arzobispo de Valencia -Mariano Barrio y Fernández (18051876)- un pectoral de esmeraldas y rosetas que había pedido y por el que daría otro de menos valor así como dinero en metálico. ${ }^{144}$ El 14 de marzo de 1864 se exponen a la corporación dos pectorales para otros dos canónigos que han de ser ordenados obispos de Badajoz y Oviedo. ${ }^{145}$ Son Joaquín Hernández y Herrero (1806-1868) y José Luis Montagut Rubio (1805-1877). El 8 de mayo de 1894, el canónigo-chantre de Segorbe, sobrino de Hernández, devuelve un pectoral, radiado con chispas de diamantes y con once topacios, así como un anillo con un topacio. ${ }^{146}$ El 3 de julio de 1876, entra otra pieza de pontifical. El báculo pastoral que el obispo de Tuy -Ramón García y Antón (1851-1876), antiguo canónigo de Valencia- lega a la catedral. En un principio el cabildo no lo aceptó porque le pedían no borrar la inscripción que tenía, condición que los herederos del prelado dispensan a los canónigos para que puedan disponer libremente de él. ${ }^{147}$

El cardenal Luis de la Lastra y Cuesta (1803-1876) era canónigo-doctoral de la Metropolitana cuando fue preconizado obispo de Orense. Años después sería arzobispo de Sevilla. El cabildo le regaló un pectoral de esmeraldas con una cadena de oro y una sortija. El 5 de agosto de 1876 el deán presenta a los capitulares un estuche con esas piezas que son devueltas a la Seo "para que pueda obsequiar [el cabildo] a qualquier otro individuo de su seno que sea preconizado al obispado". ${ }^{148}$

\section{Destrucción y fundición de piezas de plata: 1812 y 1823}

La catedral perdió la mayoría de la orfebrería en dos fundiciones ordenadas por los gobernantes de la nación en 1812 y 1823. En plena Guerra del Francés (1808-1813), los canónigos quisieron salvar cuanto podían y para ello trasladaron gran parte del Tesoro a Alicante, Ibiza y Palma de Mallorca. Aunque alguna vez se ha publicado parte de este episodio tan lamentable, ${ }^{149}$ veamos cómo suceden los acontecimientos. El 22 de marzo de 1809 deciden dar dos mil libras al canónigo Antonio Valentín Criado "para los gastos en la conducción de las santas reliquias y alajas de esta santa iglesia". 150 Unas semanas más tarde, el 11 de abril, leen una carta del capitán general del reino que pide abran los cajones de las reliquias, para reconocerlas y elaborar un inventario. Todo ello es "para desimpresionar al público", que cree que en esas cajas "se han comprehendido muchos millones de reales". Los capitulares acceden, pues las reliquias están en Alicante. ${ }^{151}$ El 1 de mayo exponen en Cabildo la Real Orden que manda enviar las alhajas a Sevilla. El cabildo ordena vuelvan de Alicante para examinarlas y registrar las que no sean precisas para el culto. ${ }^{152}$ El 1 de septiembre conocen que el canónigo José Faustino Alcedo (1775-1809), que guardaba las reliquias en Alicante, ha fallecido en aquella ciudad. Deciden escribir al beneficiado Pedro Vicente Calvo, que le acompañaba, indicándole que depositan en él su confianza y que provea el regreso de todos los cajones a Valencia por mar, sin perderos de vista. ${ }^{153}$

La guerra y los problemas continúan y, a principios del año siguiente, el 11 de enero de 1810, leen un oficio del arzobispo, junto a una Real Orden, encargándoles de nuevo que manden las alhajas a Sevilla. Deciden "se hagan inmediatamente venir las halajas que se extrajeron de esta santa iglesia para preservarlas de la rapiña y profanación del enemigo y que se contente así al señor arzobispo". ${ }^{154}$ La Regencia de España apremia y el 15 de enero exponen dos Reales Órdenes. Una de ellas insiste, una vez más, en enviar a Sevilla las alhajas

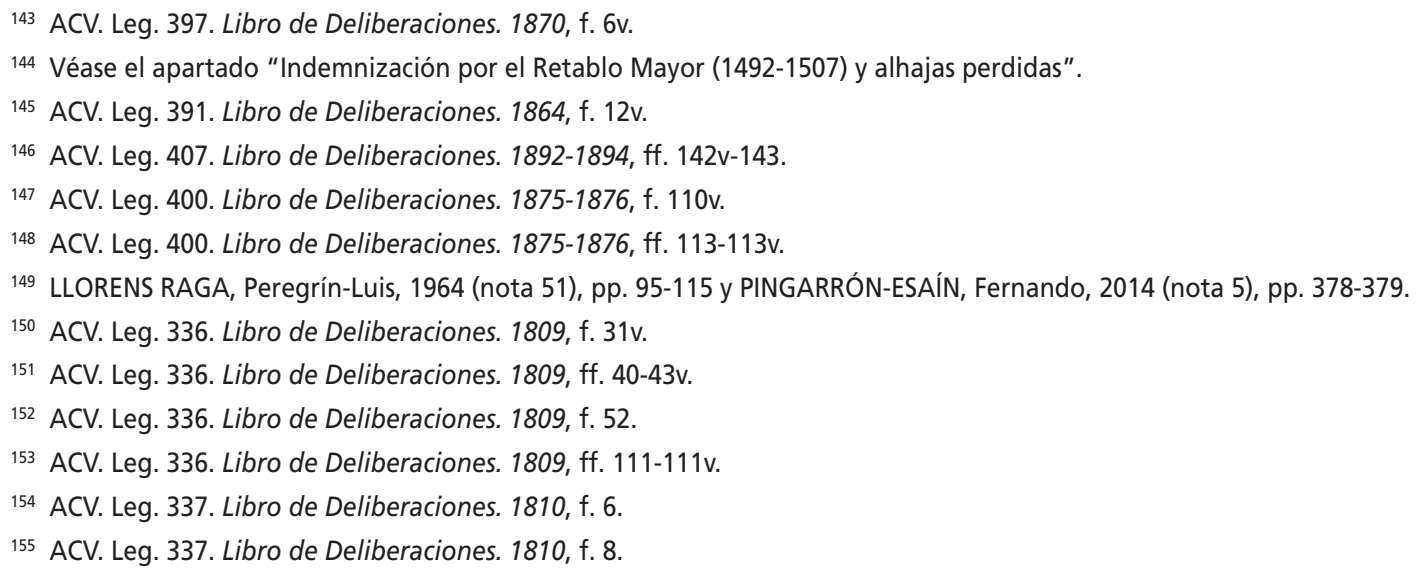


que no sean precisas para el culto. ${ }^{155}$ Los capitulares no pierden el tiempo y, el 26 de febrero, el canónigo José Rivero ya ha reconocido los cajones de la plata en Valencia, Ilevándose una malísima impresión porque

había visto con mucho dolor las muchas averías que havían padecido varios de sus relicarios y que, considerando que igual suerte habría cabido a los quadros, planchones y figuras de plata del Altar Mayor, si porque el cabildo estimase colocarlo otra vez, / que sería muy costoso y la Fábrica se encontraba notablemente impeñada o porque se contemplare dar esta plata a beneficio de las estrechíssimas urgencias del Estado, no habiendo lugar seguro en la santa iglesia

A la vista de este informe, el cabildo decide quitar el marco de madera de cada cuadro del retablo y ponerlos en cajas más pequeñas "fáciles de transportarse en caso de premura a paraje más seguro". También han de encajonarse mejor las reliquias y hacer una lista de blandones, candeleros y otras piezas de plata disponiéndolas para lo que decidan los capitulares. ${ }^{156}$

El 14 de marzo leen otro oficio del arzobispo junto con otro del capitán general. Les indican que la Casa de la Moneda ha sido establecida en Valencia y esperan que contribuyan a su buen funcionamiento. Los canónigos deciden, entonces, mandar allí las lámparas de la iglesia excepto las dos del Sacramento del Altar Mayor, la del Trasagrario, las del Cristo y la Virgen del Coro y los ocho blandones mayores "ínterin bolviese la demás plata embarcada, de la qual se extraería únicamente la precisa e indispensable para el culto". ${ }^{157}$ El 22 de marzo encargan el asunto de la plata a los canónigos Antonio Valentín Criado y Felipe Miralles (1795-1810) ${ }^{158}$ y, el 8 de junio, estipulan los estipendios de las personas que se encargaron de las reliquias en Alicante. ${ }^{159}$

El tiempo corre y, el 15 de abril de 1811, las reliquias ya están en Ibiza, pues ha regresado de allí
Pablo Acedo Rico (1794-1826), que les informa. Deciden escribir al obispo y cabildo de aquella diócesis para agradecerles su acogida. ${ }^{160} \mathrm{El} 8$ de julio conocen que el canónigo Bertrán y Alegre, que custodiaba las reliquias en Ibiza, falleció el 18 de junio. Nombran al beneficiado Pedro Vicente Calvo para que vaya ${ }^{161} \mathrm{y}$, unos días más tarde, el 15 de julio, le otorgan escritura de poderes para que "se incaute" de las reliquias "y no pueda transportar[las] a paraje alguno sin expresa orden y voluntad del ylustrísimo cabildo". ${ }^{162}$ En el Cabildo del 2 de diciembre exponen que la Junta de Partido pide una lista de la plata dada por las iglesias y la que queda por entregar, pues muchas iglesias no lo han hecho. Así mismo leen la carta del 25 de noviembre donde se pide "se eche mano de estas alhajas para socorrer las urgencias del Estado y quitar al enemigo este cebo más a su codicia". ${ }^{163}$

Con todos estos acontecimientos, entramos en el primer año luctuoso para el Tesoro de la Seo, cuando en el mes de mayo funden en Palma de Mallorca muchas piezas. Las joyas estaban en la catedral de Mallorca en diecinueve cajas custodiadas por Pedro Vicente Calvo. Este beneficiado de la Seo elaboró un cuidadoso inventario de todo lo que estaba a su cargo en febrero de ese 1812. Algunas volvieron, como el Santo Cáliz ${ }^{164}$ o la Paz de Reyes, ${ }^{165}$ pero la gran mayoría no. Entre ellas estaba la Custodia Mayor en el cajón $19^{\circ}$ "La gran custodia de magnífica echura de plata sobredorada, Oro, perlas, y piedras preciosísimas", así como la maltrecha imagen de la Virgen María con el Niño del cuerpo de gloria del Retablo Mayor. ${ }^{166}$

El 18 de marzo de 1812 dos canónigos dan cuenta de la plata que han visto en la iglesia y los capitulares nombran a José Rivero, junto a los otros dos, para que "separada la plata necesaria para el culto, se vendiese la restante a la mejor estimación posible, a cuya medida se veía precisado el ylustrí-

\footnotetext{
156 ACV. Leg. 337. Libro de Deliberaciones. 1810, ff. 25v-26.

157 ACV. Leg. 377. Libro de Deliberaciones. 1810, f. 29v. SANCHIS SIVERA, José, 1909 (nota 4), p. 430, da cuenta de esta entrega a la Casa de la Moneda.

158 ACV. Leg. 377. Libro de Deliberaciones. 1810, f. 33v.

159 ACV. Leg. 337. Libro de Deliberaciones. 1810, ff. 78v.-79.

160 ACV. Leg. 338. Libro de Deliberaciones. 1811, f. 64v.

161 ACV. Leg. 338. Libro de Deliberaciones. 1811, f. 115v.

162 ACV. Leg. 338. Libro de Deliberaciones. 1811, f. 132

163 ACV. Leg. 338. Libro de Deliberaciones. 1811, ff. 223v.-224v.

164 Cajón $9^{\circ}$ "Un Cofrecito de plata, que contiene el Cáliz de Agata, que sirvió en la Cena del Señor".

165 Cajón $3^{\circ}$ "Una Paz de Oro esmaltado con algunos diamantes, y la efigie del Niño Jesús sentado"

166 BOADA SALOM, Jaume. "La moneda a Mallorca durante la Guerra del Francés i tres tresors catedralicis". Acta Numismática, 2014, n 44, pp. 233-241.
} 
simo cabildo para facilitar el alivio de la Fábrica" por la contribución pagada por las campanas del Miguelete. ${ }^{167}$ El 14 de abril deciden que la plata quede reducida a numerario y se enajene. ${ }^{168}$

En el Cabildo del 14 de julio de 1813 Pedro Calvo les informa por carta desde Mallorca que está muy feliz porque los franceses han abandonado Valencia. Relata que pasó por grandes oprobios con las alhajas y reliquias, pues tuvo que "entregarlas y sin apoyo para defenderlas, me vi en los mayores apuros sin poder describir el fin de tan amar / ga situación". Ahora las reliquias honrarán de nuevo la catedral "y aunque el volverlas sin sus adornos me es muy sensible, me queda la satisfacción de que hice quanto pude para conservarlo todo", pero no pudo ser por el "depotismo e irreligión de los comisionados para el despojo". El cabildo le contesta agradeciéndole su favor y le dice que lo importante son las reliquias, como él mismo indicaba. Que espere las órdenes que le comunicará. ${ }^{169}$ En estas dos cartas advertimos que los capitulares y el beneficiado Calvo todavía tienen la concepción medieval de que el Tesoro de la catedral son las reliquias y no la plata y el oro. Lo otro, lo que se ha perdido, no son sino "adornos". En el Cabildo del 23 de agosto de 1813, acuerdan escribir a Calvo para que "por la primera proporción segura, se ponga en camino con las reliquias y demás que tiene a su cargo, cuidando mucho lleguen con seguridad a esta santa iglesia". ${ }^{170} \mathrm{El}$ 15 de octubre convienen que algunos de ellos tomen "razón exacta de la plata y demás alhajas que pasaron a Mallorca" para que todo ello "conste con la debida formalidad y autenticidad" e informen al cabildo para tomar un acuerdo. ${ }^{171}$ En otro Cabildo del mes siguiente, el 3 de noviembre, el canónigo Zamora (1798-1822) comunica que ha examinado las cuentas y papeles de Pedro
Calvo encontrándolo todo en orden. Los capitulares gratifican a Calvo con nueve mil reales. ${ }^{172}$

El otro año difícil para el Tesoro de la catedral es 1823. ${ }^{173}$ Está en relación directa con la intervención de los "Cien mil hijos de san Luis" que Francia envió para auxiliar al absolutista y felón Fernando VII (1784-1833). En el Cabildo del 22 de abril de 1823 se leen las disposiciones por las que las Cortes de España piden entreguen la plata de las iglesias para que el enemigo no se apropie de los tesoros. Ello aconteció en muchos templos no solo en la catedral. La colegiata de Xàtiva (La Costera) también guarda en su archivo el mismo tipo de noticias. ${ }^{174}$ Al día siguiente, los capitulares acuerdan colaborar con los comisionados que quieren los metales preciosos al mismo tiempo que reivindicar las necesidades de la Metropolitana para el culto y la devoción. Ese mismo día, el 23 de abril, a las cuatro de la tarde, llegan los delegados para reconocer los preciados objetos y los canónigos entregan la primera remesa. El Sr. Rivero ha hecho un inventario que se adjunta a las Actas Capitulares. ${ }^{175}$ El día 24, a las diez de la mañana, donan la segunda remesa y, a las cuatro de la tarde, la tercera. ${ }^{176}$ En la primera entrega dan cincuenta candeleros pequeños, ${ }^{177}$ cuatro candeleros más, de altura "como de un palmo", y una sacra con varios relieves. En la segunda una imagen de San Luis Bertrán -labrada en 1671 por el platero flamenco Josep Seguers (1667-1713) y costeada por la Generalitat del reino-, cuatro cartelas de su peana y dos piezas de madera forradas de plata que forman la base. Además dos incensarios -uno sin cadenas y otro con ellas, este último donado por el Sr. Rivero-, una bandeja de dos palmos de diámetro, una calderilla con pie y asa donada por el Sr. Rivero, seis blandones de plata de tres palmos, también regalados por el Sr. Rivero.

167 ACV. Leg. 339. Libro de Deliberaciones. 1812, f. 55.

168 ACV. Leg. 339. Libro de Deliberaciones. 1812, ff. 143v-144. SANCHIS SIVERA, José, 1909 (nota 4), p. 430, da cuenta de esta venta.

169 ACV. Leg. 340. Libro de Deliberaciones. 1813, ff. 218v.-219v.

170 ACV. Leg. 340. Libro de Deliberaciones. 1813, ff. 269v.-270.

171 ACV. Leg. 340. Libro de Deliberaciones. 1813, ff. 357-357v.

172 ACV. Leg. 340. Libro de Deliberaciones. 1813, ff. 384-384v.

173 Aparte de las noticias de archivo, para la fundición de plata de 1823 véase PINGARRÓN-ESAíN, Fernando, 2014 (nota 5), pp. 379-380.

174 PÉREZ GIMÉNEZ, Juan Ignacio. Thesaurus Collegiatae. Historia y avatares del patrimonio artístico de la Seu de Xàtiva. Xàtiva: Iglesia Colegial Basílica de Santa María. Aula de Cultura Beato Viñes, 2014, pp. 197-206. La mayoría del tesoro que dieron no volvió a la colegiata.

175 Apéndice Documental, Doc. I.

176 ACV. Leg. 350. Libro de Deliberaciones. 1823, ff. 23-24v.

177 Estos proceden de la remesa que Gaspar Quinzà labró a partir de 1777, pagados por la Fábrica. 
En la tercera entrega los comisionados recogen ocho bordones "de los que sirven para asistir al Facistol", un incensario donado por el Sr. Rivero, dos candeleros de los que usan los infantillos para el servicio del altar, seis blandoncillos y una "Cruz grande con su Crucifixo" y las dos únicas lámparas del Altar Mayor. Una ostentaba las armas del patriarca Ribera y la otra la del Gremio de Armeros. ${ }^{178}$ Los gobernantes piden más plata y demandan la imagen de la Virgen María del desaparecido Retablo Mayor perdida en 1812. En el Cabildo del 27 de abril de 1823 contestan al Jefe Superior político de Valencia diciéndole que se fundió en Palma de Mallorca y que solo disponen de una pequeña que sirve para las procesiones claustrales. ${ }^{179}$

La fundición se efectúa sin demora. Un documento del 2 de mayo de 1823 les expone que van a proceder con la plata en la Casa de la Moneda y pide a los capitulares que manden alguien para asistir al acto. ${ }^{180}$ En la Palabreta de ese día nombran al canónigo Joaquín Ferraz (1810-1847). ${ }^{181}$

No hay bastante con la plata desaparecida y así solicitan más piezas. En el Cabildo del 1 de junio de 1823 dan comisión a los canónigos Joaquín Ferraz y Vicente Llopis (1779182-1854) para una nueva entrega. ${ }^{183}$ Dos días más tarde, el 3 de junio, está escrita una carta al vicario general y al cabildo por la que les comunican que pasaran a recoger las piezas marcadas con la letra $A,{ }^{184}$ "pero que no entren en la fundición hasta que se acuerde lo conveniente en la Junta de Recursos". ${ }^{185}$ Estas últimas consiguen salvarse y llegan hasta julio de 1936 en que desaparecen para siempre. De otra de las piezas sabemos hoy un poco más. Por las razones que fueren, seguramente de carácter piadoso, la cabeza, manos y atributos de la imagen de San Luis Bertrán no fueron destruidos. Así lo indican el Inventario de 1907 y el libro del Dr. Sanchis Sivera (1867-1937). Estas fuentes ponen de manifiesto que la imagen era de madera en esos años, pero el resto, así como las andas, de plata.
Hace un tiempo nos preguntábamos cómo podía suceder esto, pues el Inventario de 1785 expone claramente que todo el conjunto era de plata. ${ }^{186}$ La única explicación es la fundición acaecida en mayo de 1823.

\section{Otras peticiones de entrega y plata rescatada. 1836-1839}

Otra nube negra debido a posibles fundiciones por el Gobierno se cierne sobre algunas piezas del Tesoro a partir de 1836. Este año es cuando la reina-regente María Cristina de Borbón Dos Sicilias (1806-1878), ayudada por los políticos liberales, comienza numerosas reformas que darán como consecuencia la eliminación de los colegios y gremios artesanales por citar una de ellas. Otra vez es la prevención de la pérdida de las piezas la que argumentan las autoridades. El 27 de octubre de ese año leen un oficio de la Comisión de Armamento y Defensa de la provincia, que participa los Reales Decretos de los días 6 y 7 de los corrientes. El oficio "manda que para que las facciones no se apoderen de los caudales, plata, alajas y demás efectos de valor de las yglesias, como se han hecho en algunos puntos, sean trasladados inmediatamente a las respectivas capitales y puntos fortificados donde se depositaran con la debida separación y formalidad". La comisión política ordena se coloquen esa tarde todas las cosas de valor en la metropolitana a cargo de D. Ramón Cerveró. El cabildo acuerda colaborar en todo y nombra algunos capitulares para que ayuden. ${ }^{187}$

Esta notificación debió de causar impacto en Valencia y alguna institución reclamó la plata que en el pasado había dejado en la Seo, pues pensaban que algo malo podría suceder. Así, en la Palabreta del 31 de octubre de 1837, el Ayuntamiento de Valencia reclama las andas e imagen de San Vicente Ferrer que costeó en 1606 y depositó en la catedral. Ello lo hace "a fin de que no fuese comprendido en la venta dispuesta por las Cortes". Los capitulares están de acuerdo "con dicha tras-

\footnotetext{
178 ACV. Leg. 350. Libro de Deliberaciones. 1823, s/f., pero entre los folios 24 y 25.

179 ACV. Leg. 350. Libro de Deliberaciones. 1823, f. 25.

180 ACV. Leg. 350. Libro de Deliberaciones. 1823, s/f., pero entre los folios 25 y 26.

181 ACV. Leg. 350. Libro de Deliberaciones. 1823, f. 25v

182 ACV. Leg. 440. Libro de Oposiciones a canónigo magistral. 1820. La fecha de nacimiento está tomada de este expediente.

183 ACV. Leg. 350. Libro de Deliberaciones. 1823, f. 33.

184 Apéndice Documental. Doc. II.

185 ACV. Leg. 350. Libro de Deliberaciones. 1823, s/f., pero entre los folios 33 y 34.

186 COTS MORATÓ, Francisco de Paula, 2013 (nota 83), pp. 151-152.

187 ACV. Leg. 363. Libro de Deliberaciones. 1836, ff. 54-54v.
} 
lación, siempre que / vencieran dicho obstáculo con la Diputación Provincial". ${ }^{188}$

Malas noticias se advierten en la Palabreta del 13 de noviembre 1837. Leen una carta indicándoles "que en cumplimiento de la Real Orden del 18 de octubre último les prevenía la Diputación Provincial, con fecha del 4, se constituyesen en esta santa yglesia a practicar la clasificación de las alajas no indispensables para el decente servicio del culto". ${ }^{189}$ Los canónigos sospecharon que la plata, como aconteció en 1823, podía ser expoliada y fundida. Debieron de acudir a la reina-regente, pues en el Cabildo del 8 de junio de 1838, exponen que esta decide "que se conserven en esta Metropolitana las estatuas de plata de San Vicente Mártir y de San Vicente Ferrer no habiendo considerado en el mismo caso la de San Pedro Apóstol que debía remitirse a la Casa de Moneda de Sevilla". El cabildo, entonces, pide averigüen si pertenece a la Seo o a la parroquia de San Pedro. ${ }^{190}$ La respuesta vendría el 15 de junio de 1838. Indican que, después de revisar el Archivo, "aparecía ser propiedad de la yglesia la estatua del apóstol san Pedro, que reclama la Diputación Provincial" como demuestra la lectura del manuscrito de Juan Pahoner (†1781). ${ }^{191}$ Así las cosas, cabe decir que, el 22 de agosto de 1838, la imagen todavía no había sido reconocida ni pesada. ${ }^{192}$ La situación iba a peor, pero un canónigo rescató el relicario al pagar bastante dinero al gobernador. De este modo figura el 15 de marzo de 1839 cuando la autoridad comunica la recepción de seis mil quinientos cuarenta reales "a que ascendió el valor de la imagen de plata de San Pedro Apóstol", por lo que la entregará a los representantes de la catedral. ${ }^{193}$ Muchos años después, el 15 de febrero de 1849, exponen un oficio de los albaceas de D. Valentín Zorrilla de Velasco (+1847). Él fue quien redimió el 13 de marzo de 1839 la imagen de San Pedro. En este oficio hacen saber que si alguna vez autoridad alguna quisiese quedarse con ella, la donación quedaría sin efecto y el cabildo debería entregarla a sus parientes más próximos. ${ }^{194}$

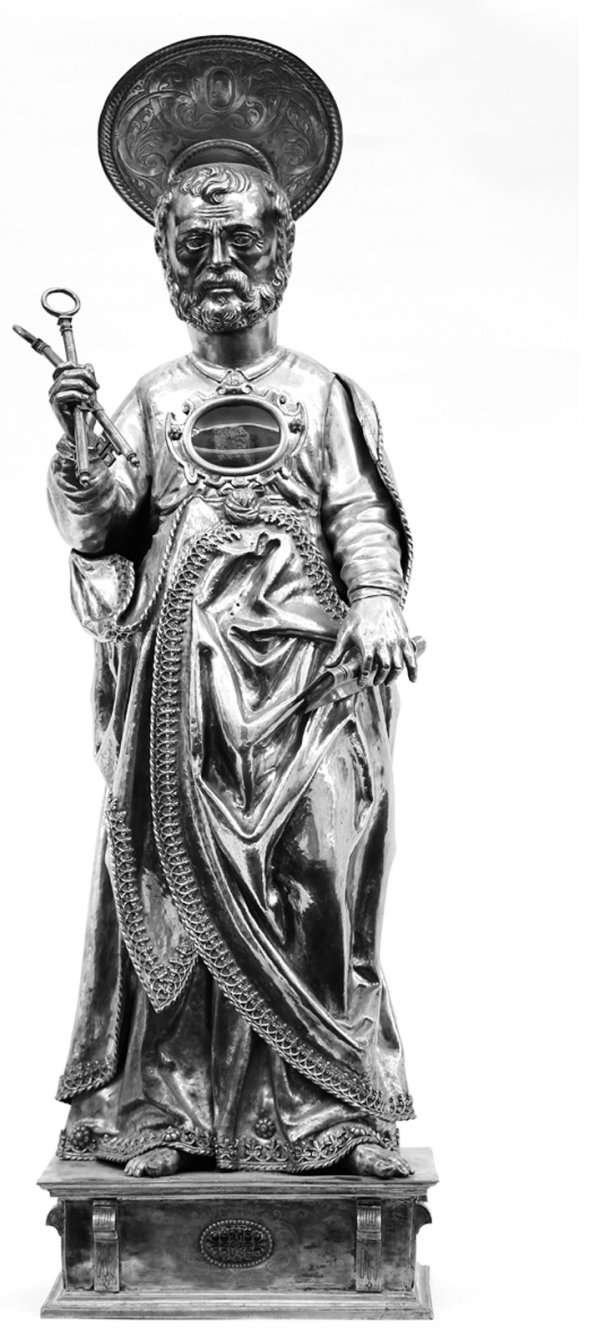

Fig. 8. Plateros valencianos. Imagen-relicario de san Pedro. Siglo XV, 1607 y 1620. Foto A. Sáiz. (C) Archivo de la Catedral de Valencia.

La imagen-relicario de San Pedro (fig. 8) tiene una factura complicada, aunque cada vez es más clara para los estudiosos. La mayoría de los investigadores la datan en el siglo $\mathrm{XV}$, partiendo de la reseña

188 ACV. Leg. 364. Libro de Deliberaciones. 1837, ff. 44v.-45.

189 ACV. Leg. 364. Libro de Deliberaciones. 1837, f. 46v.

190 ACV. Leg. 365. Libro de Deliberaciones. 1838, f. 24v.

191 ACV. Leg. 365. Libro de Deliberaciones. 1838, f. 26v. "Sea el primero el que mereció ser esco / gido por cabeza de la militante yglesia, el señor san Pedro, cuyo reliquiario es una ymagen de plata sobredorada de cuerpo entero de tres palmos de alto y de mucho peso. La peaña es quadrada y en los quatro frentes tiene un óvalo esmaltado de azul. Lleva en la mano derecha dos llaves y en la yzquierda un libro. En el pecho tiene un cristal y, dentro de él, una vestica o nuca de cuello del mismo santo apóstol". Cfr. ACV. Manuscritos. Sig. 377. PAHONER, Juan. Especies perdidas. Tomo I, ff. 158-158v.

192 ACV. Leg. 365. Libro de Deliberaciones. 1838, f. 35.

193 ACV. Leg. 366. Libro de Deliberaciones. 1839, f. 7v.

194 ACV. Leg. 376. Libro de Deliberaciones. 1849, ff. 9-9v. El oficio está cosido entre los folios 8 y 9. 
de Sanchis Sivera, ${ }^{195}$ aunque algunos indican también la existencia de partes del siglo XVII. ${ }^{196}$ Lo cierto es que el cuerpo y túnica pertenecen al último tercio del siglo XV, el busto, brazos y cabeza son de 1607 y la peana, cartela de la teca y aureola fueron labradas por Eloi Camanyes (1546?$1630)$ en $1620 .{ }^{197}$ El apóstol está en pie, en contraposto, sujeta con una mano el libro de la Ley y con la otra las llaves del Reino. La túnica y la parte baja recuerdan las figuras femeninas de la escultura de la Baja Edad Media. ${ }^{198}$ No así el cuerpo y la cabeza. Ambas, sobre todo esta última, muestra una grandeza y una serenidad que manifiestan la belleza ideal del Renacimiento. La peana y las obras del prestigioso platero Eloi Camañes, especializado en esculturas de plata, están en relación con el arte de la corte que se expande por la península en la primera mitad del siglo XVII, con sus consabidos botones de esmalte nielado azul.

\section{Indemnización por el Retablo Mayor (1492- 1507) y alhajas perdidas ${ }^{199}$}

Debido a la fundición irregular de la plata y oro por la Regencia de España en Palma de Mallorca, el cabildo recibió una compensación económica. Tenemos noticia de ella en los Cabildos de la segunda mitad del siglo XIX, cuando piensan en construir un nuevo Retablo Mayor. Desde fechas tempranas, los capitulares intentan reponer el retablo como hicieron con la Custodia del Corpus Christi. Sabemos que el 1 de agosto de 1828 el arquitecto Joaquín Tomás (1769-1834) ha formado un proyecto. Lo ha examinado el arzobispo y le parece bien. Piden al arquitecto lo ponga en limpio y lo presente al cabildo. ${ }^{200}$

Las noticias escasean durante muchos años. En el Cabildo del 9 de noviembre de 1859 el secretario informa que tienen un crédito a su favor de cua- trocientas treinta y siete mil, ciento treinta y cuatro reales y diecinueve maravedíes "procedente de la plata que, de orden de la Junta Central, se trasladó a Mallorca en el año 1810 y, por orden de la Regencia del Reyno de 1812, se fundió en la ciudad de Palma". Indica dicho secretario que hay un señor que puede gestionar ante el Gobierno de España lo que les corresponde. El cabildo acuerda que la Junta de Hacienda y el Sr. Roque Rubio se reúnan con este señor y le informen con posterioridad. ${ }^{201}$ Será tiempo después cuando vemos nuevas gestiones. El 10 de mayo de 1861 exponen que el vicario capitular pide le den los testimonios "de las disposiciones del Gobierno que ocasionaron la ocupación de los valores referidos y las cartelas" que tiene el cabildo "en justificación de la entrega e importe de los mismos". Los capitulares acuerdan entregárselo. ${ }^{202}$

Las gestiones son muy intensas hasta el punto de pedir a la reina Isabel II que use su influencia para conseguir lo que pretenden. En el Cabildo del 17 de junio de 1861 el canónigo Ramón García (18511876) explica que ha ido a Madrid para recuperar el dinero que el Gobierno de España les debe como reparación de las pérdidas de plata de 1812 . También indica que la reina le ha recibido en audiencia en dos ocasiones y ha mediado ante el ministro de Gracia y Justicia para ello. Después de algún contratiempo el ministro ofrece dar doscientos cincuenta mil reales de vellón para el Altar Mayor. El Sr. García les comunica que si no hubiera sido por "la munificencia y religiosos sentimientos" de la reina no lo habría conseguido. ${ }^{203}$

No solo el dinero ofrecido por el gobierno es necesario. Hay un intento de que colaboren muchas personas de influencia por motivos diversos. En el Cabildo del 1 de septiembre de 1862 el deán manifiesta que el arzobispo -Mariano Barrio y Fer-

\footnotetext{
195 SANCHIS SIVERA, José, 1909 (nota 4), p. 401.

196 GAVARA PRIOR, Joan Jesús. "Relicario en San Pedro". En: GAVARA PRIOR, J. J. (com). Reliquias y relicarios en la expansión mediterránea de la Corona de Aragón. El Tesoro de la catedral de Valencia (Catálogo de Exposición). Valencia: Generalitat Valenciana, 1998, p. 168, ficha n 16 y SOLER D'HYVER, Carlos. "Relicario de San Pedro". En: ANDALÒ, L. y MIRA, E. (com.). Los Borja. Del mundo gótico al universo renacentista (Catálogo de Exposición). Valencia: Generalitat Valenciana, 2001, p. 360, ficha $n^{\circ} 74$.

197 COTS MORATÓ, Francisco de Paula. "En torno al platero valenciano Eloi Camanyes (*1546?-+1630). Datos para su estudio". Saitabi, 1996, Volum Extraordinari 1996, pp. 168-169 y 178. Fue limpiado en 2016 en el IVACOR donde comprobamos las tres fases de dorado y factura de la pieza.

198 Agradezco a Inmaculada Traver Badenes esta observación.

199 La mayoría de las noticias del Retablo Mayor de la segunda mitad del siglo XIX están en PINGARRÓN-ESAíN, Fernando, 2014 (nota 5), pp. 373-415.y, por lo tanto, las obviamos.

200 ACV. Leg. 355. Libro de Deliberaciones. 1828, f. 8

201 ACV. Leg. 386. Libro de Deliberaciones. 1859, ff. 50-50v.

202 ACV. Leg. 388. Libro de Deliberaciones. 1861, f. 23v.

203 ACV. Leg. 388. Libro de Deliberaciones. 1761, ff. 49-50v.
} 
nández (1805-1876)- ha entregado a la Junta de Hacienda diez y ocho mil reales de vellón y el pectoral con topacios. Todo ello es en compensación del pectoral y anillo de esmeraldas que le regaló el cabildo "cuya cantidad era destinada a la obra del Altar Mayor". El deán también informa que el arzobispo quiere obtener dos sortijas más: una de esmeraldas y otra de topacios, y, asimismo, dará ciento sesenta reales de vellón. Los canónigos, habiéndose pronunciado a favor la Junta de Hacienda, lo aprueban. ${ }^{204}$ Finalmente, el 26 de junio de 1865, sabemos que el obispo de Tuy, Ramón García y Antón, solicita le vendan uno de los anillos que hay en la catedral. Los capitulares acceden "y que su importe se destine a la construcción del Altar Mayor que se está obrando". ${ }^{205}$

\section{Noticias varias}

Hay un grupo de noticias referidas a asuntos diversos, pero relacionadas de un modo u otro con las piezas de plata y oro de la Seo. La primera es del 22 de septiembre de 1783 cuando el canónigo Félix Rico (1774-1796) comenta a sus compañeros que "algunas de las alaxas y adornos" de la catedral se prestan y "o se buelben deterioradas o se pierden". El cabildo acuerda que, si no es con su permiso, no se presten a excepción de las que necesitare el arzobispo y sus sucesores. ${ }^{206}$ Diez años más tarde, el 1 de marzo de 1793, el arzobispo y cabildo ofrecen al rey sus personas, rentas, plata y alhajas de la catedral de un modo un tanto servil. Les contestan que lo tendrán en cuenta. ${ }^{207}$

El Retablo Mayor ocupaba los desvelos de los capitulares. Lo habían restaurado y limpiado en 1629 y en 1635 . Conocemos una limpieza más. Esta también es intensa casi como las realizadas los años antes mencionados. El 2 de marzo de 1797 el fabriquero Sr. Roa (1782-1814) propone limpiar el Retablo Mayor de plata "que estaba muy empañado del polvo e incienso", para la beatificación de Juan de Ribera (1532-1611). El cabildo lo autoriza bajo la dirección del mismo Sr. Roa. ${ }^{208}$ La llevó a cabo el platero de la catedral Bernat Quinzà. ${ }^{209}$

Ya en el ochocientos, encontramos otras referencias. En el Cabildo del 22 de mayo de 1824 comisionan a dos canónigos para vender algunas piedras preciosas, especialmente esmeraldas, que están en el Depósito para socorrer las urgentes necesidades de la Seo informando puntualmente al cabildo. ${ }^{210}$ El 8 de mayo de 1825 el Sr. Llopis expone que vendan la pedrería suelta que está en el Depósito y acuerdan convocar una reunión para otro día. ${ }^{211}$ Dentro de las enajenaciones de la segunda mitad del siglo XIX, cuando se desprenden de los catorce tapices flamencos, joyas y piezas de orfebrería, el cabildo intenta vender la Paz de Reyes, formada por dos bellísimos trabajos franceses de ca. 1400 y ca. 1540. No lo consiguen y desisten en $1914 .^{212}$

La memoria de la Palabreta del 28 de noviembre de 1843 recoge que el Ayuntamiento de Valencia les pide dos azafates de plata que usarán el día 1 de diciembre "para recibir el paño del Real Pendón para la proclamación de su majestad la reina doña Isabel II".213

Ya en el siglo $X X$, los capitulares autorizan el 15 de julio de 1922 a la Real Cofradía de la Virgen de los Desamparados que la imagen principal del camarín pueda lucir la corona de la "del Cabildo" de modo provisional. ${ }^{214}$ Esta corona fue labrada por el platero de la catedral Gaspar Lleó en $1703 .{ }^{215}$ Recordemos que ese año de 1922 es el

204 ACV. Leg. 389. Libro de Deliberaciones. 1862, ff. $21 \mathrm{v} .-22$.

${ }^{205}$ ACV. Leg. 392. Libro de Deliberaciones. 1865, ff. 50-50v.

206 ACV. Leg. 310. Libro de Deliberaciones. 1783, f. 87.

207 ACV. Leg. 320. Libro de Deliberaciones. 1793, ff. 25 y siguientes.

208 ACV. Leg. 324. Libro de Deliberaciones. 1797, f. 23v.

209 COTS MORATÓ, Francisco de Paula, 2007 (nota 8), p. 81. Véase también SANCHIS SIVERA, José, 1909 ( $n^{\circ}$ 4), pp. 174-175. Es completamente falso que el artífice que limpió el retablo fuera el pintor-dorador Roberto Albors como asegura PINGARRÓNEISAíN, Fernando, 2014 (nota 5), p. 378. Como había sucedido en siglos anteriores el restaurador fue el platero de la catedral. Los recibos de Albors, $n^{\circ} 29$ y 30, dan fe de encarnadura y dorados, no de la reforma del retablo. Cfr. ACV. Leg. 1243. Cuentas de Fábrica, Tesorería y Armario. 1796 en 1797.

210 ACV. Leg. 351. Libro de Deliberaciones. 1824, ff. 78-78v.

211 ACV. Leg. 352. Libro de Deliberaciones. 1825, f. 60.

212 COTS MORATÓ, Francisco de Paula. "Algunas consideraciones sobre la Paz de Reyes de la catedral de Valencia". En: RIVAS CARMONA, J. y GARCÍA ZAPATA, I. J. (ed.). Estudios de Platería. Murcia: Publicaciones de la Universidad de Murcia, 2017 pp. 157-166.

213 ACV. Leg. 370. Libro de Deliberaciones. 1843, ff. 39-39v.

214 ACV. Leg. 416. Libro de Deliberaciones. 1920-1923, f. 88v. 
previo a la solemne coronación canónica de la imagen principal de los Desamparados cuando sustituyen la antigua pieza de perlas sobre cartón por la nueva y rica de José Sugrañes. Esta última desaparece en julio de 1936.

$$
\text { *** }
$$

Como hemos visto, los Libros de las Deliberaciones del cabildo proporcionan infinidad de noticias, algunas conocidas ya por otras series como los Libros de Fábrica o Tesorería o anteriores publicaciones, pero muchas otras no. Las fundiciones de 1812 y 1823 merman el ajuar de plata de la catedral que llega, muy diezmado ya, a la Guerra Civil, cuando se remata la vorágine destructora. El Relicario es lo más completo del Tesoro que conserva la metropolitana de tiempos pasados. Fue salvado, según parece, por los artistas del Círculo de Bellas Artes en julio de 1936. En cuanto a los artífices orfebres tan solo hemos advertido en todo el siglo XIX el nombramiento de un solo platero de la Seo, cuando lo habitual en centurias anteriores es que no faltara este cargo. A modo de ejemplo, señalamos que, a principios del XVII, la catedral mantiene dos artistas fijos en nómina: el platero y el bordador. Aunque muchas obras se han identificado, otras no ha sido posible hacerlo, pero, hoy sabemos un poco más de todo el ajuar de la metropolitana, conocimientos que se completarán con la consulta de otras series documentales de su archivo.

\section{Apéndice documental}

1823, abril 25. Valencia.

Inventario de la plata de la catedral de Valencia. ACV. Leg. 350. Libro de Deliberaciones. S. f. Cosido entre los folios 33 y 34

Cit. Pingarrón-Esain, F. (2014), p. 380.

Ynventario de la plata existente en la Santa Yglesia para usos de la misma y que presenta el cabildo a los señores comisionados para su conocimiento y el del señor gefe superior político en cumplimiento de la circular del mismo del 21 de abril del corriente año:

Número $1^{\circ}$. Primeramente, tres estatuas grandes, con sus peanas o andas y varas de plata, que repre- sentan a los gloriosos patrones de esta ciudad san Vicente Mártir, san Vicente Ferrer y san Luis Bertrán, todas de estatura natural. Una por la segunda remesa. Van las dos en depósito. ${ }^{216}$

Número $2^{\circ}$. Un tabernáculo y andas con sus varas de plata, que sirve para el Santo Cáliz y demás reliquias que suelen colocarse en él y se sacan procesionalmente.

Número $3^{\circ}$. Ytem, siete candeleros grandes con su cruz correspondiente para el servicio del Altar Mayor en los días de mayor solemnidad y singularmente quando celebra el prelado de pontifical.

Número $4^{\circ}$. Ytem, otros seis candeleros grandes para igual servicio en el Altar y en los días menos solemnes con su cruz correspondiente. Tercera. ${ }^{217}$

$5^{\circ}$. Ytem, otros seis candeleros grandes con su cruz correspondiente que entregó el señor Rivero procedentes del monasterio suprimido de gerónimos de Gandia. ${ }^{218}$ Segunda y Tercera.

$6^{a}$. Ytem, sesenta candeleros pequeños, como de media vara, para varios usos de esta santa yglesia. Cincuenta en la primera, quedan diez.

$7^{\circ}$. Ytem, ocho ochavados chatos y pequeños, como de a quarta, para iguales destinos. Cuatro en la primera. I

$8^{\circ}$. Ytem, quatro bandejas entre grandes y pequeñas para el servicio del Altar Mayor y demás usos de la yglesia. Una en la segunda.

$9^{\circ}$. Ytem, seis incensarios y cinco navetas. Uno en la tercera.

$10^{\circ}$. Ytem, dos incensarios que entregó el señor Rivero procedentes de conventos suprimidos. Fueron en la segunda.

$11^{\circ}$. Ytem, dos cruces parroquiales.

$12^{\circ}$. Ytem, otra cruz sin asta que entregó el señor Rivero. Se devolvió.

$13^{\circ}$. Ytem, diez y nueve bordones inclusos, el del pertiguero, perrero, nuncio, zeladores y caperos. Ocho en la tercera.

$14^{\circ}$. Ytem, dos sacras para el Altar Mayor. Una en la primera.

$15^{\circ}$. Ytem, otra sacra existente en la capilla de Santo Tomás. Va.

$16^{\text {a }}$. Ytem, dos atriles grandes y uno pequeño par el servicio del Altar Mayor. Va el pequeño.

$17^{\circ}$. Ytem, una calderilla con dos hisopos. Segunda.

$18^{\circ}$. Ytem, un frontal de plata y bronce dorado al fuego. Va en depósito.

$19^{\circ}$. Ytem, otro de chascarilla de plata muy usado. No. $20^{\circ}$. Ytem, dos torrecillas o faroles para quando se descubre el Santísimo. Van.

$21^{\circ}$. Ytem, dos lámparas únicas que hay en el presbiterio. Tercera.

215 RODRIGO PERTEGÁS, José. Historia de la Antigua y Real Cofradía de Nuestra Señora de los Inocentes Mártires y Desamparados, de su veneranda imagen y de su capilla. Valencia: Imprenta Hijo de F. Vives Mora, 1922, p. 368. Hay una edición de 2010 que cambia la paginación.

216 La anotaciones que matizan cuántas se entregan están al margen izquierdo en el documento original

217 Se refiere a la tercera entrega de plata.

218 Es el monasterio de San Jerónimo de Cotalba. 
$22^{\circ}$. Ytem, el Arca del Monumento en que se reserva el Señor el Jueves y Viernes Santo. Va en depósito. $23^{\circ}$. Ytem, dos juegos de vinageras con sus platillos y campanilla.

$24^{\circ}$. Ytem, otro juego de vinageras de cristal con perfiles de plata.

$25^{\circ}$. Ytem, otra cruz pequeña para bendecir las pilas. $26^{\circ}$. Ytem, seis canelobres o candeleros para los ynfantillos. Dos en la tercera.

$27^{\circ}$. Ytem, un hostiero.

$28^{\circ}$. Ytem, tres jarros de plata para el servicio del altar. Van dos.

$29^{\circ}$. Ytem, quatro palmatorias para ídem. Van.

$30^{\circ}$. Ytem, la arquilla del cirio pasqual. No.

$31^{\circ}$. Ytem, la bola y cruz del pendón de la Purísima. Va.

$32^{\circ}$. Ytem, un dosel pequeño para el Santo Cáliz. No.

$33^{\circ}$. Ytem, un dosel grande que sirve para el Mani-

fiesto del Santísimo Sacramento. No.

$34^{\circ}$. Ytem, quatro campanillas. Van tres.

$35^{\circ}$. Ytem, un platillo para vinajeras. [Va]..$^{219}$

$36^{\circ}$. Ytem, una cruz de plata de dos palmos. Van.

$37^{\circ}$. Ytem, un busto de medio cuerpo de Santo Tomás de Villanueva, colocado en su altar, con la cabeza del santo en el pecho. No.

$38^{\circ}$. Ytem, quatro pares u ocho vinageras. Van un par.

39. Ytem, un juego completo de sacras. Van.

$40^{\circ}$. Ytem, dos azafates. Va uno.

$41^{\circ}$. Ytem, un jarro $[\mathrm{Va}]$.

$42^{\circ}$. Ytem, dos cruces [Va].

$43^{\circ}$. Ytem, un atril. Van..$^{220}$

$44^{\circ}$. Ytem, siete palmatorias. Van dos.

$45^{\circ}$. Ytem, quatro vasos. No.

$46^{\circ}$. Ytem, siete platillos para vinajeras. Van cuatro.

$47^{\circ}$. Ytem, dos campanillas. [Van].

$48^{\circ}$. Ytem, dos hostieros. [Van].

$49^{\circ}$. Ytem, un par y medio, o tres vinageras. [Van].

$50^{\circ}$. Ytem, tres palmatorias. Van. ${ }^{221} /$

$51^{\circ}$. Ytem, tres platillos. [Van].

$52^{\circ}$. Ytem, una campanilla. [Va].

$53^{\circ}$. Ytem, un hostiero. Van. ${ }^{222}$

Valencia, 25 de abril de 1823.

Joaquín Ferraz (rúbrica).

Vicente Llopis (rúbrica).

\section{II}

1823, junio 4. Valencia.

Inventario de la plata de la catedral entregada a la comisión.

ACV. Leg. 350. Libro de Deliberaciones. S. f. Cosido entre los folios 33 y 34.

Cit. Pingarrón-Esain, F. (2014), p. 380.

Ynventario de las alhajas de plata de esta Santa Yglesia Metropolitana, entregadas a la comisión nombrada por el señor gefe político superior de la provincia, para cumplir con el decreto de las Cortes que manda la recaudación de la misma:

A. Dos estatuas grandes con sus peañas o andas, con sus varas de plata, que representan a san Vicente Mártir y san Vicente Ferrer, patronos de esta ciudad.

Dos sacras.

Dos atriles, el uno pequeño.

A. Un frontal de plata y bronce dorado a fuego. Dos torrecillas o faroles para cuando se descubre el Santísimo.

A. Un arca para el Monumento.

Dos jarros, nueve palmatorias, una bola y cruz del pendón de la Purísima, seis campanillas, tres hostiarios, ocho platillos, tres cruces, una de dos palmos, dos y medio pares de vinageras, un azafate.

Santa Yglesia Metropolitana de Valencia. 4 de junio 1823.

Nota: Quedan por ahora en depósito en esta Santa / Yglesia las dos estatuas de san Vicente Mártir y san Vicente Ferrer, el frontal de plata y bronce dorado y el arca para el Monumento.

Valencia ut supra.

Joaquín Ferraz (rúbrica).

Vicente Llopis (rúbrica).

Jayme Rostam (rúbrica).

Antonio García (rúbrica). José Mateu (rúbrica).

\footnotetext{
${ }^{219}$ Cuando aparece la nota entre corchetes se refiere a que se entrega la pieza, pero en el original se agrupa con la anterior. Quiere decir que van la 35 y 36.

220 Se refiere a que van la 41,42 y 43 .

221 Van de la 47 a la 50.

222 Van la 51,52 y 53.
} 
